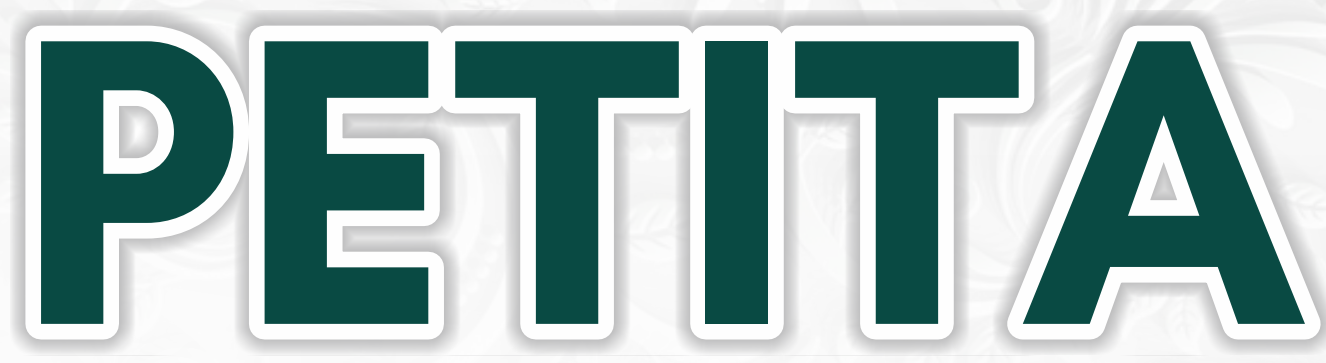

Jurnal Kajian Ilmu Hukum dan Syariah

Published By:

Lembaga Kajian Konstitusi Indonesia (LKKI)

Fakultas Syariah dan Hukum Universitas Islam Negeri (UIN) Ar-Raniry Banda Aceh Jl. Syeikh Abdul Rauf, Kopelma Darussalam Banda Aceh, Telp: 0651-7557442 Website: http://petita.ar-raniry.ac.id 


\section{Contents}

EKSISTENSI BITCOIN DALAM PERSPEKTIF MAQĀṢID AL-SYAR'ĪYAH

(Dara Lidia, Jabbar Sabil \& Syarifuddin Usman / 104-113)

TATACARA PENETAPAN BATAS TANAH DIKALANGAN MASYARAKAT KECAMATAN BAKONGAN TIMUR DITINJAU MENURUT KONSEP MAL 'UQAR

(Elida Gusmira, Saifuddin Sa'dan \& Faisal Fauzan / 114-127)

TINJAUAN HUKUM ISLAM TERHADAP SISTEM PENYELESAIAN WANPRESTASI PRODUK ARRUM DI PEGADAIAN SYARIAH ACEH BESAR

(Asdi Marni, Edi Darmawijaya \& Faisal Fauzan / 128-136)

SANKSI ADAT BAGI PELAKU KEKERASAN FISIK DITINJAU MENURUT HUKUM PIDANA ISLAM (Studi Terhadap Adat Kampung Taman Firdaus, Kecamatan Pintu Rime Gayo, Kabupaten Bener Meriah)

(Abdul Rahman, Jamhuri \& Irwansyah / 137-144)

DAMPAK PEMEKARAN DAERAH PADA PELAYANAN PUBLIK DITINJAU MENURUT SISTEM HUKUM INDONESIA

(Ali Abubakar, Sitti Mawar \& Nurdin Syah / 145-155)

MARK UP PENJUALAN HARGA TIKET BUS PADA LOKET TERMINAL BATOH DALAM PERSPEKTIF TAS'IR AL-JABAR (Studi tentang Penyimpangan Harga Dari Ketetapan Organda Banda Aceh)

(Aris Rahmaddillah / 156-169)

PROSES PENIMBANGAN IKAN DI TEMPAT PELELANGAN IKAN LAMPULO KOTA BANDA ACEH DALAM PERSPEKTIF MA'QUD 'ALAIH

(Alfata / 170-175)

SANKSI BAGI PELAKU ZINA (Perbandingan Qanun No. 6 Tahun 2014 Dan Enakmen Jenayah Syariah Negeri Selangor No. 9 Tahun 1995 Seksyen 25)

(Ali Abubakar, Badrul Munir \& Cempaka Sari Harahap / 176-200) 
PETITA: Jurnal Kajian Ilmu Hukum dan Syariah

Volume 3, Number 2, 2018

P-ISSN: 2502-8006 E-ISSN: 2549-8274

DOI: https://doi.org/10.22373/petita.v3i2.54

\title{
SANKSI BAGI PELAKU ZINA \\ (Perbandingan Qanun No. 6 Tahun 2014 Dan Enakmen Jenayah Syariah Negeri Selangor No. 9 Tahun 1995 Seksyen 25)
}

\author{
Ali Abubakar, Badrul Munir \& Cempaka Sari Harahap \\ Fakultas Syariah dan Hukum UIN Ar-Raniry \\ Email: aliabubakar@ar-raniry.ac.id
}

\begin{abstract}
Abstrack: Penalties for adulterers have been regulated by law in a number of countries with their respective sanctions. One such arrangement is through Aceh Qanun No. 6 of 2014 concerning the Law of Jinayat and the Enactment of the Syariah Law of Selangor No. 9 of 1995 Sex. 25. But the penalties set out in the Aceh Qanun are different from the punishment of adultery perpetrators regulated in Selangor State Sharia Youth Enactments, therefore this study aims to find out what penalties are contained in the Aceh Qanun and the Selangor State Islamic Law, and what lies behind this difference. to get the answer to the problem of punishment for adulterers, the writer uses descriptive-comparative method. This research is categorized as library research. Punishment regulated in Qanun No. 6 of 2014 concerning jinayat law is a lash of 100 (one hundred) times without distinguishing between the muhsan and ghair muhsan, whereas in the Enakmen regulates adultery sanctions on three categories: fines, imprisonment and caning (sebat), this sentence is determined in the religious court (Syar Court 'iyah in Aceh or the Syariah Court in Selangor). The Selangor State Islamic Law Enactment regulates more criminal acts but the provisions of the sanctions are more severe in the Aceh Qanun. This is because in Selangor in the determination of penalties for perpetrators of crimes in Malaysia using Ta'zir's punishment and more looking at the benefits and local wisdom of Selangor State. While the Qanun is based on the punishment of hudud, which hudud is a punishment that has been determined the form and level by Allah SWT. In the author's opinion, punishment that is more in line with the sanctions of adultery is a punishment that is regulated in the Aceh Qanun because according to the provisions set out in the text namely 100 (one hundred) lashes, although it does not distinguish between muhsan adulterers and adulterers Ghair muhsan.
\end{abstract}

\section{Keywords: Penalties for Adulterers, Punishment, Islamic Jinayat Law}

\begin{abstract}
Abstrak: Hukuman bagi penzina telah diatur oleh hukum di sejumlah negara dengan sanksi masing-masing. Salah satu pengaturan tersebut adalah melalui Qanun Aceh No. 6 tahun 2014 tentang Hukum Jinayat dan Penetapan Hukum Syariah Selangor No. 9 tahun 1995 pasal 25. Tetapi hukuman yang ditetapkan dalam Qanun Aceh berbeda dengan hukuman terhadap penzina yang diatur dalam Undang-Undang Selangor State Sharia Youth Enactments. Penelitian ini termasuk penelitian kepustakaan. Hukuman yang diatur dalam Qanun No. 6 tahun 2014 tentang hukum jinayat adalah 100 kali cambuk tanpa membedakan antara muhsan dan ghair muhsan, sedangkan dalam State Sharia Youth Enactments sanksi perzinahan terbagi menjadi tiga kategori: denda, hukuman penjara dan hukuman cambuk, hukuman ini ditentukan di pengadilan agama (Pengadilan Syar'iyah di Aceh atau Pengadilan Syariah di Selangor). Qanun didasarkan pada hukuman hudud, dimana hudud merupakan hukuman yang telah ditentukan bentuk dan tingkatannya oleh Allah SWT. Hukuman yang lebih sesuai untuk sanksi perzinaan adalah hukuman yang diatur dalam Qanun Aceh karena sesuai ketentuan yang diatur dalam Al-Quran yaitu 100 (seratus) cambuk.
\end{abstract}

Kata kunci: Hukuman bagi pezina, Hukuman, Hukum Jinayat Islam 


\section{Pendahuluan}

Zina adalah persetubuhan antara seorang laki-laki atau lebih dengan seorang perempuan atau lebih tanpa ikatan perkawinan dengan kerelaan kedua belah pihak. ${ }^{1}$ Sedangkan dalam Kamus Besar Bahasa Indonesia zina didefinisikan kedalam dua arti, yang pertama perbuatan bersenggama antara laki-laki dan perempuan yang tidak terikat oleh hubungan pernikahan (perkawinan), sedangkan yang kedua perbuatan bersenggama seorang perempuan yang terikat perkawinan dengan seorang laki-laki yang bukan suaminya. ${ }^{2}$

Terdapat beberapa ayat di dalam al-Quran yang mengharamkan jarimah zina dan bahkan mendekatinya saja dilarang sebagaimana disebutkan dalam Firman Allah Q. S. Al-Isra' 17: 32 yang Artinya:" Dan janganlah kamu mendekati zina; Sesungguhnya zina itu adalah suatu perbuatan yang keji. dan suatu jalan yang buruk.

Dan juga Hadits dari Nabi Saw:

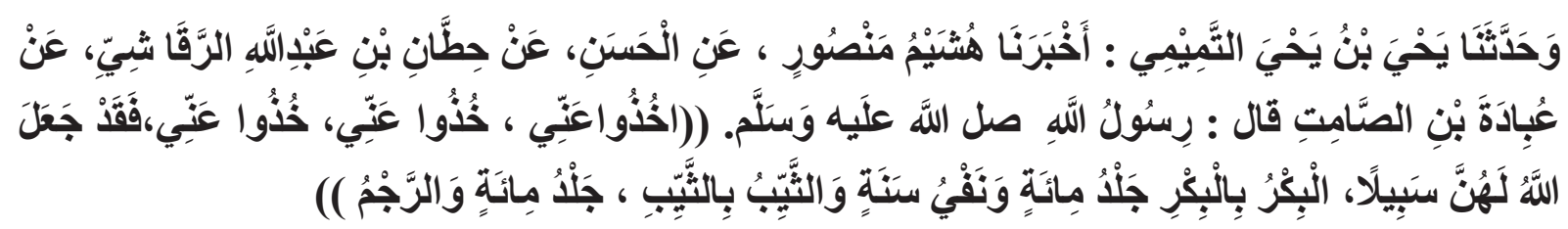

Artinya: Yahya bin Yahya at- Tamimi menyampaikan kepada kami dari Husaim yang mengabarkan dari Manshur, dari al- Hasan, dari Hithan bin Abdullah ar-Raqasyi, dari Ubadah bin Shamit bahwa Rasulullah bersabda, "Ambillah dariku (tentang hukum zina), ambillah dariku (tentang hukum zina), ambilah dariku (tentang hukum zina). Sesungguhnya Allah telah menetapkan hukuman bagi kaum wanita (yang bezina). Jika seorang laki-laki belum pernah menikah (perjaka) berzina dengan seorang wanita yang belum pernah menikah (perawan) hukumannya adalah seratus kali cambuk dan diasingkan selama satu tahun, sedangkan lakilaki dan wanita yang telah pernah menikah berzina maka hukuman nya dicambuk seratus kali dan di rajam. ${ }^{3}$

Dalam fiqh ada dua jenis jarimah (tindak kejahatan yang dilarang oleh syariat Islam) zina, yaitu zina muhsan dan ghairu muhsan. Zina muhsan ialah zina yang pelakunya berstatus suami, istri, duda, atau janda. Artinya, pelaku adalah orang yang masih dalam status pernikahan atau pernah menikah secara sah. Adapun ghairu muhsan ialah zina yang pelakunya belum pernah menikah secara sah dan tidak sedang dalam ikatan pernikahan (perkawinan). ${ }^{4}$

Terhadap kedua jenis jarimah di atas syariat Islam memberlakukan sanksi yang berlainan. Pertama: Hukuman bagi pelaku zina yang belum pernah menikah (ghairu muhsan) maka hukumannya dicambuk sebanyak seratus kali cambukan, yang mana sanksi ini secara eksplisit ditegaskan di dalam firman Allah, QS. An-Nur (2)yang Artinya: Perempuan dan laki-laki yang berzina, Maka deralah tiap-tiap seorang dari keduanya seratus kali dera, dan janganlah belas kasihan kepada keduanya mencegah kamu untuk (menjalankan) agama (hukum) Allah, jika kamu beriman kepada Allah, dan hari akhirat, dan hendaklah (pelaksanaan) hukuman mereka disaksikan oleh sekumpulan orang-orang yang beriman. ${ }^{5}$

Sedangkan yang Kedua: hukuman bagi pezina yang telah pernah menikah secara sah (muhsan) adalah di rajam, dikubur hingga leher dan dilempari dengan batu hingga mati,

1 Dinas Syariat Islam Aceh, Hukum Jinayat Dan Hukum Acara Jinayat (Naskah Aceh 2015), hlm. 8.

2 Departemen Pendidikan Nasional, Kamus Besar Bahasa Indonesia (Gramedia 2011), hlm. 1571.

3 Muslim bin Al-Hajjaj al-Qusyairi an-Naisaburi, Ensiklopedi Hadits Shahih Muslim (Almahira 2012), hlm. 109.

4 Masyarofah dan M Nurul Irfan, Fiqh Jinayah (Amzah 2016).

5 Al-Bukhari, Sahih Al-Bukhari, Jilid IV, hlm. 2733. 
baik laki-laki maupun perempuan. ${ }^{6}$

Hukuman ini diadopsi atau diaatur dalam qanun No. 6 tahun 2014 tentang hukum jinayat dalam Pasal 33 ayat 1, tentang hukum zina, yang berbunyi:

"Setiap orang yang dengan sengaja melakukan Jarimah zina, diancam dengan 'Uqubat Hudud cambuk 100 kali."

Hukuman dalam Qanun Jinayat ini berbeda dengan hukuman yang diatur dalam aturan hukum Negeri Selangor yang mana dalam Enakmen Jenayah Syariah Selangor No. 9 Tahun 1995, mengatur aturan hukum tentang zina dalam seksyen 25 ayat 1 disebutkan:

"Mana-mana orang laki-laki yang melakukan persetubuhan dengan orang perempuan yang bukan istrinya yang sah adalah melakukan suatu kesalahan dan apabila disabitkan(dibuktikan) kesalahan boleh didenda tidak melebihi lima ribu ringgit (Rp. 17.500,000,00) atau dipenjarakan selama tempoh(waktu) tidak melebihi tiga tahun atau disebat (dipukul/dicambuk) tidak melebihi enam sebatan atau dihukum dengan mana-mana kombinasi hukuman itu"

Jadi dari kedua bunyi peraturan zina di atas, terdapat perbedaan dalam penetapan hukuman bagi pelaku zina yang mana pada Qanun No. 6 Tahun 2014 Pasal 33 hanya mengatur satu jenis hukuman saja, sedangkan yang diatur dalam Enakmen Jenayah Syariah Selangor No. 9 Tahun 1995 Seksyen 25 di atas, terlihat bahwa hukum bagi pelaku perzinaan dapat dikategorikan kepada tiga kategori hukuman, yaitu hukuman (sanksi) denda, penjara atau keduanya, dan sebatan (cambuk).

Perbedaan ini menarik jika dibandingkan atau dihubungkan dengan kategori jarimah yang dibuat ulama yaitu hudud, qishas dan ta'zir. Yang mana hudud secara etimologis merupakan bentuk jamak dari kata had yaitu النَّهْيُ (larangan, pencegahan). Adapun secara terminologis Al-Jurjani mengartikan sebagai sanksi yang telah ditentukan dan wajib dilaksanakan secara hak karena Allah Swt, sementara itu sebagian ahli fiqh sebagaimana dikutip oleh Abdul Qadir Audah, berpendapat bahwa had ialah sanksi yang telah ditentukan secara syara'.7

Hukuman dalam hudud terbagi kepada tiga macam, yaitu, hukuman mati, hukuman potong tangan dan cambuk disertai dengan pengasingan. Hukuman mati diberlakukan dalam empat macam tintak pidana, yaitu: 1. Murtad 2. Zina muhsan 3. Meninggalkan shalat karena malas dan 4. Membegal (merampok). Adapun kukuman potong tangan diberlakukan pada tindak pidana yaitu, 1. Pencurian 2. Membegal (merampok) disertai perampasan harta. Sedangkan hukuman cambuk diberlakukan pada tiga kategori pidana yaitu, 1. Mengkonsumsi minuman memabukkan (khamar) 2. Menuduh berzina dan 3. Zina selain muhsan.

Ulama fikih membagi jenis-jenis perbuatan tersebut kedalam tujuh jenis perbuatan. Pembagian ini didasarkan pada pemisahan antara hak Allah dan hak hamba, serta bentuk ancaman hukumannya yang sudah ditetapkan dalam al-Quran dan hadits. Perbuatan tersebut meliputi:ar-riddah (murtad), al-baghy (pemberontakan), zina, qadzaf (tuduhan palsu zina), as-sariqah (pencurian), al-hirabah (perampokan), Shurb al-khamr (peminum khamar). ${ }^{8}$

Adapun qishas dalam fiqh jinayah ada dua macam, yaitu yang pertama qishas karena melakukan jarimah pembunuhan dan yang kedua qishas karena melakukan jarimah penganiayaan. Adapun pengertian qishas yang dikemukakan oleh al-Jarjani, yaitu

$6 \quad$ Saleh Al-Fauzan, Fiqih Sehari-Hari (Gema Insani 2005), hlm. 820.

$7 \quad$ Irfan (n 4), hlm. 13-14.

8 Topo Santoso, Membumikan Hukum Pidana Islam (Gema Insani Press 2003), hlm. 22-23. 
mengenakan sebuah tindakan (sanksi hukum) kepada pelaku persis seperti tindakan yang dilakukan oleh pelaku tersebut (terhadap korban). Sementara dalam Al-Mu'jam alWasit, qishash diartikan dengan menjatuhkan sanksi hukum kepada pelaku tindak pidana sama persis dengan tindak pidana yang dilakukan, Nyawa dengan nyawa dan anggota tubuh dibayar dengan anggota tubuh. ${ }^{9}$ Ta'zir, adalah bentuk masdar dari kata yang secara etimologis berarti menolak dan mencegah. Sedangkan menurut terminologis Wahbah Al-Zuhaili menberikan pengertian ta'zir adalah hukuman-hukuman yang secara syara' tidak ditegaskan mengenai ukurannya. Syariat Islam menyerahkan kepada penguasa negara untuk menentukan sanksi terhadap pelaku tindak pidana yang sesuai dengan kejahatannya. ${ }^{10}$

Hukuman bagi pezina telah ditetapkan di dalam al-Quran. Sebagai mana penjelasan ulama bahwa hukuman zina termasuk kepada jarimah hudud, dan hukuman tersebut tidak dapat dirubah lagi, baik ditambah maupun dikurang.

\section{Hukuman Zina Dalam Fiqh}

Dalam hukum Islam, perzinaan dianggap sebagai suatu perbuatan yang sangat terkutuk, pendapat ini disepakati oleh ulama, kecuali perbedaan hukumnya. Menurut sebagian ulama tanpa memandang pelakunya, baik dilakukan oleh orang yang belum menikah atau orang yang telah menikah, selama persetubuhan tersebut berada di luar kerangka pernikahan, hal itu disebut sebagai zina dan dianggap sebagai perbuatan melawan hukum. Juga tidak mengrangi nilai pemidanaanya, walaupun hal itu dilakukan secara sukarela atau suka sama suka. ${ }^{11}$

Abu Zahrah mengatakan bahwa, zina adalah hubungan kelamin antara laki-laki dan perempuan tanpa adanya ikatan perkawinan yang sah, dilakukan dengan sadar dan tanpa adanya unsur subhat. ${ }^{12}$ Adapun Abdul Qadir Audah berpendapat bahwa zina ialah hubungan badan yang diharamkan dan disengaja oleh pelakunya. ${ }^{13}$

Zina juga berarti aktivitas seksual yang melibatkan organ reproduksi yang diharamkan, membangkitkan nafsu syahwat serta menetapkan adanya had. Meskipun memasukkan pucuk atau kadar tertentu dari penis seorang lelaki, sekalipun impoten, berkondom, ke dalam lubang vagina atau lubang anus laki-laki atau perempuan yang tidak halal. ${ }^{14}$

\section{Legalitas Hukum Zina}

Banyak fuqaha' yang berpendapat bahwa penetapan hukuman berzina dilakukan secara bertahap, sama seperti proses pengharaman khamr dan penetapan kewajiban puasa. Dimasa awal, hukuman zina berbentuk penyiksaan, ejekan dan kecaman. ${ }^{15}$ Allah SWT berfirman, (An-Nisa': 16)

Artinya: "Dan terhadap dua orang yang melakukan perbuatan keji diantara kamu, maka berilah hukuman kepada keduanya, kemudian jika keduanya bertobat danmemperbaiki diri, maka biarkanlah mereka." (An-Nisa': 16)

Tahapan berikutnya adalah ditahan di dalam rumah. Allah SWT berfirman,yang Artinya

"Dan (terhadap) para wanita yang mengerjakan perbuatan keji, hendaklah ada

$9 \quad \operatorname{Irfan}(\mathrm{n} 4)$, hlm. 4-5.

10 Wahbah Al-Zuhaili, Al-Fiqh Al-Islami Wa Adillatuh (Jilid VII, Dar Al-Fikr 1997), hlm. 530.

11 Muslim Zainuddin, Problematika Hukuman Cambuk Di Aceh (Dinas Syariat Islam Aceh 2012), hlm. 2930 .

12 Ibid.

13 Nurul Irfan dan Masyrofah, Figh Jinayah (Sinar Grafika Offset 2014), hlm. 18.

14 Wahbah Zuhaili, Fiqh Imam Syafi'i (Almahira 2010), hlm. 260.

15 Sayyid Sabiq, Fiqih Sunnah (Insan Kamil 2016), hlm. 244. 
empat orang saksi di antara kamu (yang menyaksikannya), kemudian apabila mereka telah memberi persaksian, maka kurunglah mereka (wanita-wanita itu) dalam rumah sampai mereka menemui ajalnya, atau sampai Allah memberi jalan lain kepadanya." (An-Nisa': 15)

Dalam tafsir Fi-Zhilalil Qu'ran dijelaskan bahwa sejak awal Islam memilih untuk mengucilkan dan menjauhkan wanita-wanita keji dari masyarakat, apabila telah terbukti bahwa mereka melakukan perbuatan keji itu (zina). ${ }^{16}$

Setelah kedua firman Allah tersebut dia atas, barulah turun firman (perintah) Allah yang mengatur tentang pengaharaman atau sanksi bagi pelaku zina. Persoalanpun jadi tuntas. Allah menunjukan jalan yang dimaksud, yaitu menghukum pezina bujang dengan 100 deraan (cambuk) dan pezina yang telah menikah dengan rajam hingga mati. ${ }^{17}$ Yang mana hukuman tersebut berlandaskan kepada firman Allah SWT dalam al-Quran, Qs. AnNur: (2)Artinya: Perempuan dan laki-laki yang berzina, Maka deralah tiap-tiap seorang dari keduanya seratus kali dera, dan janganlah belas kasihan kepada keduanya mencegah kamu untuk (menjalankan) agama (hukum) Allah, jika kamu beriman kepada Allah, dan hari akhirat, dan hendaklah (pelaksanaan) hukuman mereka disaksikan oleh sekumpulan orang-orang yang beriman. ${ }^{18}$

Tahapan tersebut dilakukan untuk mengikuti perkembangan masyarakat sehingga masyarakat dapat menerima hal itu dengan baik dan lapang dada. Adapun hukum itu ada karena untuk menjaga kesucian dan harga diri setiap muslim. Begitu juga, hal itu dilakukan agar tidak menyusahkan masyarakat dalam mengikuti perubahan hukuman yang ada sehingga mereka tidak mendapatkan kesulitan dalam menjalankan perintah agama. ${ }^{19}$

Dari tahapan-tahapan tersebut di atas dapat dipahami bahwa hukuman bagi pelaku zina tidaklah langsung kepada hukuman cambuk dan rajam, seperti yang kita ketahui bahwa hukuman bagi pelaku zina saat sekarang ini. Tetapi ada tiga tahapan, tahapan yang pertama ialah sanksi sosial, yang mana berupa ejekan atau kecaman dari orang-orang, dan sanksi yang kedua ialah dikurung di dalam rumah sampai ia menemui ajalnya, adapun sanksi yang terakhir dan berlaku sampai saat sekarang ini ialah seperti yang dijelaskan diatas 100 kali dera (cambuk) bagi pezina ghairu muhsan dan rajam bagi pelaku zina yang berstatus muhsan.

\section{Bentuk-Bentuk Hukuman}

Dalam fiqih jinayah dijelaskan bahwa kategori pelaku zina dibagi kepada dua macam, yaitu pezina Muhsan dan pezina tidak muhsan (ghairu muhsan). ${ }^{20}$

\section{Hukum bagi pezina Muhsan}

Pezina muhsan ialah orang yang sudah baliq, berakal, merdeka, dan sudah pernah bercampur dengan jalan yang sah. Dalam buku bidayatul mujtahid wa nahyatul Muqtasid menerangkan bahwa pezina muhsan adalah zina yang dilakukan oleh laki-laki dan perempuan yang sudah berkeluarga (bersuami/beristri).

Pezina muhsan juga dapat di definisikan sebagai zina yang pelakunya berstatus suami, istri, duda, ataupun janda. Artinya, pelaku adalah orang yang masih dalam status pernikahan atau pernah maenikah secara sah. ${ }^{21}$

\footnotetext{
16 Sayyid Quthb, Tafsir Fi- Zhilalil Qur'an (Gema Insani Press 2001), hlm. 299.

17 Sayyid Sabiq, Fiqh Sunah Jilid II (Al- I' tishom 2008), hlm. 601.

18 Al-Bukhari (n 5), hlm. 2733.

19 Sayyid Sabiq, Jilid III (n 15), hlm, 245.

20 Ida Noverayanti, 'Hukuman Bagi Pelaku Zina Dewasa Dengan Anak-Anak (Perbandingan Fiqh Jinayah Dan Qanun No. 6 Tahun 2014 Tentang Hukum Jinayat' (UIN Ar-Raniry 2017), hlm. 3.

21 Nurul Irfan dan Masyrofah (n 13), hlm. 20.
} 
Hukuman bagi pelaku zina yang berstatus muhsan disini para ulama selain Khawarij bersepakat adalah dirajam dengan batu hingga mati dan hukum ini tidak membedakan antara pezina laki-laki dan pezina wanita. ${ }^{22} \mathrm{Hal}$ ini berdasarkan sejumlah dalil dari asSunnah yang mutawatir, dalil ijma', serta dalil logika. ${ }^{23}$ Adapun hadits Nabi adalah sebagai berikut:

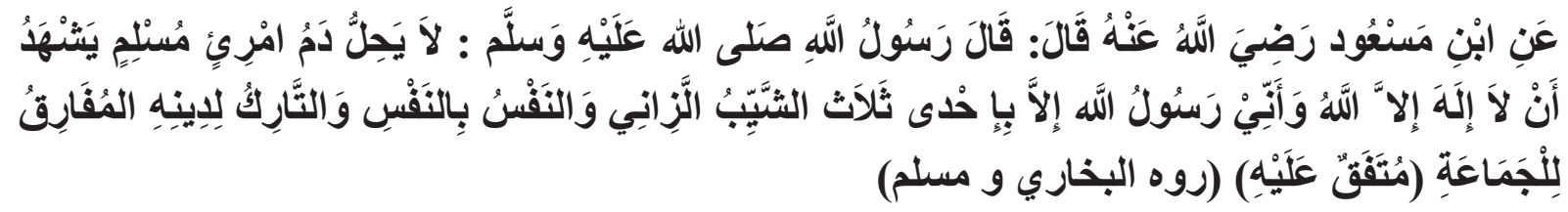

Artinya: Dari Ibnu Mas'ud ra dia berkata: Rasulullah Saw bersabda: "Tidak halal (menumpahkan) darah seorang muslim yang bersaksi bahwasanya tidak ada tuhan selain Allah Swt dan bahwasanya aku adalah utusan Allah kecuali terhadap salah satu dari tiga orang, yaitu orang yang telah menikah berzina, jiwa dengan jiwa membunuh (pembunuh), dan orang yang meninggalkan agamanya (murtad) yang memisahkan diri dar jama'ah (Mutaffaq Alaih)(Riwayat Bukhari dan Muslim). ${ }^{24}$

Begitu juga dengan kisah Ma'iz r.a., yang diriwayatkan dari berbagai jalur. Dalam riwayat tersebut diterangkan bahwa Ma'iz ra mengaku dihadapan Rasulullah Saw bahwa dirinya telah berzina, lalu beliaupun memerintahkan supaya iya dirajam. ${ }^{25}$

Juga terdapat dalil lain mengenai hukuman rajam berdasarkan hadits yang diriwayatkan dari Imron bin Husoin r.a., katanya:

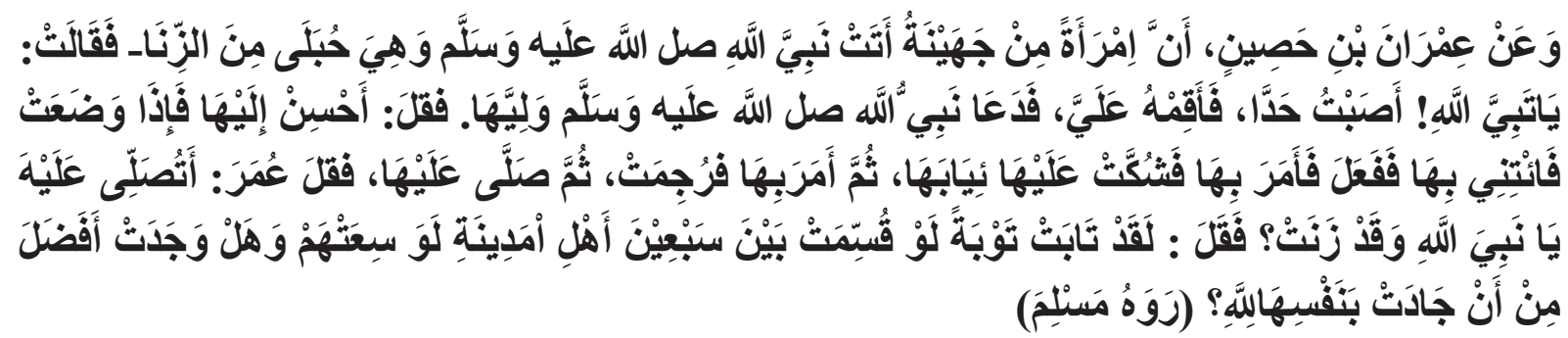

Artinya: "suatu ketika seorang wanita Bani Juhainah datang menemui Nabi Swa, dalam keadaan hamil karena zina. Wanita ini berkata "wahai Nabi Allah saya telah melakukan kesalahan, jatuhkanlah hukuman terhadap saya." Lalu Rasulullah memanggil penjaga wanita ini dan bersabda: "layanilah dia dengan baik, setelah dia melahirkan anaknya bawalah dia kepada saya. "perintah baginda ini dilaksanakan dan kemudian baginda memerintahkan agar pakaian waita ini diikatkan (supaya tidak berselek semasa dirajam). Lalu Rasulullah memerintahkan agar wanita itu dirajam. Wanita itupun dirajam. Setelah itu bagindapun menyembahyangkannya. Umar berkata "wahai Nabi Allah adakah engkau menyembahyangkan wanita yang telah berzina ini?" baginda bersabda "wanita ini telah bertaubat. Sekiranya taubatnya dibahagiakan kepada 70 orang penduduk madinah, niscaya mencukupi mereka. Adakah yang lebihbaik dari pada seseorang yang mengorbankan dirinya karena Allah?.(HR. Muslim) lafaz ini ada pada Imam Muslim No. Hadis $1240 .{ }^{26}$

Umat Islam berijma' logika menghendaki pemberlakuan hukuman semacam ini. Karena zina yang dilakukan orang yang berstatus muhsan (sudah menikah) sangat buruk dan

22 Sayyid Sabiq (n 15), hlm. 128.

23 Ibid.

24 Al-Hafizh Ibnu Hajar Al-'Asqalani, Bulughul Maram (PT Fathan Prima Media 2014), hlm. 309.

25 Ibid.

26 Ibnu Hajar Al-Asqalani, Bulughul Maram (Gema Insani 2013), hlm. 546. 
tercela, sehingga berhak mendapatkan balasan hukuman dunia yang sangat berat. ${ }^{27}$

Dengan demikian dapat disimpulkan bahwa hukuman bagi pelaku zina yang berstatus muhsan ialah dirajam yaitu, pelaku dilempari batu hingga meninggal tanpa membedakan antara pezina laki-laki dan pezina perempuan. Sebagaimana yang telah dijelaskan di atas bahwa ketetapan tersebut telah disepakati oleh ulama (jumhur).

\section{Hukum bagi pezina tidak muhsan (ghairu Muhsan)}

Pezina gairu muhsan ialah orang yang tidak mencukupi syarat-syarat zina muhsan, yaitu gadis dan bujang. ${ }^{28}$ Dan juga pezina ghairu muhsan dapat diartikan sebagai zina yang dilakukan oleh laki-laki dan perempuan yang belum menikah (gadis/jejaka). ${ }^{29}$ Artinya pelaku belum pernah menikah secara sah dan tidak sedang baerada dalam ikatan pernikahan. ${ }^{30}$

Adapun hukuman bagi pezina yang berstatus ghairu muhsan ada dua macam, yaitu:

a) Cambuk seratus kali secara merata di seluruh tubuhnya kecuali wajah dan kemaluan, agar setiap tubuh mendapat haknya.

b) Pengasingan selama satu tahun.

Paraulama sepakat hukuman bagi pezina ghairu muhsan didera seratus kali (100 kali cambukan). Hal ini berdasarkan kepada firman Allah dan hadits Nabi Saw:

1. Firman Allah SWT dalam surat An-Nur ayat 2 sebagaimana yang telah

Dijelaskan diatas tentang hukuman pelaku zina, apabila orang Islam sudah aqil balig, merdeka bukan muhsan, yaitu wajib dicambuk seratus kali, bahkan pelaksanaannya harus disaksikan oleh orang-orang yang beriman.

2. Hadis Rasulullah Saw, dari 'Ubadah bin Samit ra. ${ }^{31}$ Di dalam hadis yang sebagaimana dijelaskan diatas, hukuman bagi pezina ghair muhsan adalah jilid seratus kali dan pengasingan selama satu tahun.

Namun ulama berbeda pendapat mengenai hukum pengasingan, apakah hukuman dera dan pengasingan kedua-duanya bisa dijatuhkan kepada pelaku perzinaan yang masih lajang (ghair muhsan) sekaligus. ${ }^{32}$

Ulama Hanafiyah mengatakan, hukuman pengasingan tidak dapat ditambahkan kepada hukuman dera. Sebab Allah SWT menjadikan dera sebagai keseluruhan hukuman had zina. Sehingga jika seandainya kita juga mewajibkan hukuman pengasingan disamping hukuman dera, itu berarti hukuman dera adalah hanya sebagian dari hukuman had, sehingga hal ini merupakan bentuk penambahan terhadap nash, sementara penambahan seperti ini berarti sebuah bentuk penasakhan nash. Selain itu, pengasingan menjadikan pelaku zina berpotensi untuk melakukan perzinaan lagi, karena ia berada di tempat pengasingan jauh dari keluarga, kerabat, dan kenalan sehinga ia tidak khawatir kena malu. ${ }^{33}$

Hukuman pengasingan tersebut adalah kewenangan menjatuhkan hukuman pengasingan diserahkan kepada imam atau pemimpin, sehingga jika ia melihat adanya kebaikan dan kemaslahatan untuk menjatuhkan hukuman pengasingan kepada pelaku, maka

28 Sulaiman Rasjid, Fiqh Islam (Sinar Baru Algensindo 2017), hlm. 436.

29 Ibnu Rusyd, Bidayatul Mujtahid Wa Nihayatul Muqtashid (Akbar Media Eka Sarana 2013), hlm. 686.

30 Nurul Irfan dan Masyrofah (n 13), hlm. 20.

31 Irfan Hidayat, 'Hukum Pengasingan Bagi Pezina Ghair Muhsan (Study Perbandingan Antara Mazhab Hanafi Dan Syafi'i' (UIN Ar-Raniry 2014), hlm. 45.

32 Wahbah Az-Zuhaili, Fiqh Islam Wa Adillatuhu (Jilid 7, Gema Insani 2007), hlm. 315.

33 Ibid. 
ia mengasingkannya, sebagaimana juga imam mengambil kebijaksanaan untuk memenjarakan orang tersebut hingga dia bertobat. ${ }^{34}$

Sementara itu, imam Malik mengatakan silelaki diasingkan selama satu tahun, yakni dipenjara dikawasan dimana dia diasingkan. Sedangkan si perempuan tidak diasingkan karena dikhawatirkan akan berzina lagi akibat pengasingan tersebut. ${ }^{35}$

Sedangkan ulama Syafi'iyah dan ulama Hanabilah mengatakan, pelaku dihukum dera dan sekaligus dihukum dengan diasingkan selama satu tahun kesuatu kawasan dengan jarak yang sudah memperbolehkan untuk mengqashar shalat.

Imam asy-Syaukani mengatakan "yang jelas, kesimpulannya adalah bahwa hadits-hadits mengenai diberlakukannya hukuman pengasingan telah melampaui batas kemasyhuran yang diperhitungkan dan di syariatkan oleh ulama Hanafiah untuk hadits yang memuat hukum tambahan yang tidak tercantum di dalam al-Quran. ${ }^{36}$

Dengan keterangan ini jelaslah bahwa seseorang tidak bisa dikenai hukuman dera dan hukuman rajam sekaligus berdasarkan kesepakatan mazhab empat. Sementara ulama Zhahiriyah mengatakan, seseorang bisa dikenakan hukuman dera dan rajam sekaligus. ${ }^{37}$

Syariat Islam telah menetapkan tiga jenis hukuman untuk jarimah zina, yaitu: dera (Jilid), pengasingan (taghrib), dan rajam (dilempari batu). Hukuman ini ditinjau dari sasaran hukum..$^{38}$ yaitu:

a) Hukuman Jilid (cambuk atau dera), Menurut Maulana Muhammad Ali, Jilid berasal dari bahasa Arab yaitu jalada, artinya memukul atau melukai kulit, oleh karena itu, jalada atau dera hukuman yang terasa pada kulit hal ini lebih banyak ditujukan untuk memberi efek malu terhadap si terhukum. Hukuman cambuk berarti suatu hukuman yang di jatuhkan kepada seseorang yang melakukan perzinaan terhadap orang-orang yang belum pernah melaksanakan nikah dengan hukuman masing-masing seratus kali cambuk, baik pezina itu laki-laki maupun perempuan. ${ }^{39}$

b) Hukuman Pengasingan

Pengertian pengasingan menurut syara' adalah mengeluarkan atau mengusir orang yang berbuat zina dari kediamannya ke tempat lain yang biasa disebut pengasingan. Sedangkan pengasingan yang penulis maksud adalah seseorang diasingkan dari kampung halamannya kedaerah lain, sebab telah melanggar hukum perzinaan, sesuai dengan jarak yang telah ditetapkan dalam hukum islam. Karena pengasingan merupakan hukuman kedua bagi pelaku zina. ${ }^{40}$

c) Hukuman rajam

Menurut A. Hanafi , rajam adalah hukuman mati dengan cara dilempari dengan batu dan sejenisnya. Atau dalam pengertian lain rajam adalam membunuh orang yang berzina dengan cara melempari dengan batu dan ditujukan kepada pezina muhsan ${ }^{41}$

d) Hukuman harta, yaitu hukuman yang dikenakan kepada harta, seperti diyat, denda, dan perampasan.

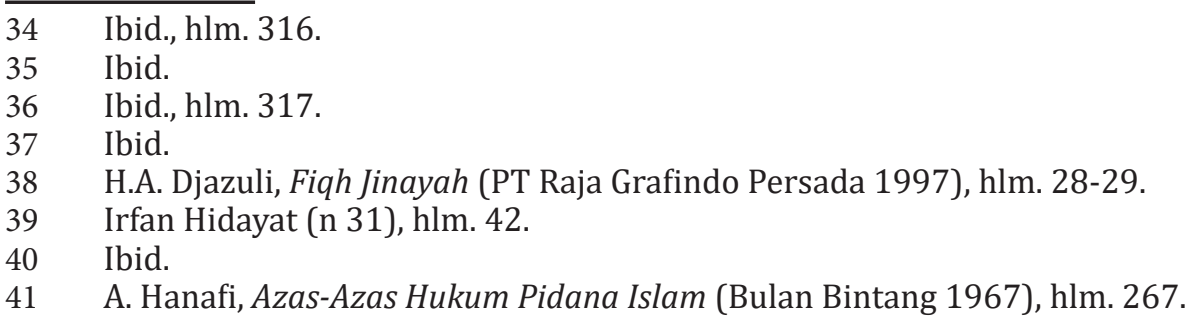


Dari uraian di atas maka penulis menyimpulkan secara umum bahwa ulama sepakat atas hukuman dera (cambuk) yang dijatuhkan atas pezina Ghairu muhsan apabila terpenuhinya syarat dan ketentuan yang telah dijelaskan di atas., namun ulama berbeda pendapat mengenai hukuman pengasingan bagi pezina yang ghairu muhsan. Ulama Hanafiah mengatakan bahwa hukuman pengasingan tersebut tidak dapat ditambahkan atas hukuman dera, karena menurut mereka dera adalah keseluruhan sanksi atas had zina. Jadi apabila ditambah dengan hukuman pengasingan tersebut maka itu termasuk penambahan terhadap nash.

\section{Tujuan Hukuman bagi pelaku zina}

Bila berbicara mengenai hukuman, asosiasi yang ada senatiasa tertuju kepasa suatu seperangkat ketentuan hukum yang memiliki sanksi serta tujuan pemberian sanksinya. Dalam hukum Islam, jenis-jenis sanksi bagi pelaku jarimah hudud telah disebutkan dengan jelas demikian pula halnya dengan jarimah qishas-diyat. Sedangkan jarimah ta'zir diserahkan kepada pengusa untuk menentukan jenis, bentuk dan ukuran sanksinya.

Tujuan pemberian hukumandalam hukum Islam adakalanya diterangkan langsung dalam nash al-Quran atau sunnah. Sebagai contoh adalah tujuan hukuman qhisas, langsung diterangkan Allah dalam firmanNya:

"Dan dalam qhisas itu ada (jaminan) kehidupan bagimu, wahai orang-orang yang berakal, agar kamu bertaqwa"

Ibnu katsir menafsirkan ayat ini dengan mengatakan bahwa penerapan hukuman qhisas mempunyai hikmah yang sangat besar untu menjaga kehidupan manusia, dimana pembunuhan juga dibalas dengan pembunuhan, sehingga orang jadi takut untuk membunuh karena nanti ia akan di bunuh pula. Dengan demikian daya preventif hukuman qhsas ini sangat efektif.

Dalam hukum Islam kajian terhadap tujuan ditetapkan suatu hukum, termasuk masalah pidana (Jarimah) dikhususkan dalam pembahasan maqasidal-Syari'ah dan maslahah. Penjabaran dari kedua tujuan tersebut dapat dilihat pada ketentuan Allah SWT terhadap hukuman zina (had as-zina) yaitu seratus (100) kali cambuk bagi yang belum kawin (ghairu muhsan) dan rajam bagi yang sudah kawin (muhsan) bertujuan untuk menjaga nasab dan menghindari dari penyakit yang berbahaya. ${ }^{42}$

Wahbah az-Zuhaili juga menerangkan beberapa tujuan ditetapkannya hukuman bagi pelaku zina, yaitu: melindungi nasab, menghindari pelanggaran nama baik seseorang, mencegah pelaku melakukan perusakan badan atau kejiwaan orang lain. Bahkan perzinaan terkadang mengakibatkan subjek atau objek pelaku (perempun atau laki-laki) divonis hukuman mati. ${ }^{43}$

Al-Yasa' Abubakar menjelaskan bahwa para ulama menyimpulkan ada beberapa tujuan pemidanaan dalam al-Quran (ajaran Islam), yang masing-masing tujuan tersebut dapat berdiri sendiri atau gabungan dari beberapa tujuan tersebut yaitu: ${ }^{44}$

a) Pembalasan atas kejahatan atau perbuatan pidana yang dilakukan;

b) Memberi efek jera, sehingga tidak lagi mengulangi perbuatan pidana;

c) Mendidik dan meperbaiki pelaku perbuatan pidana;

d) Ada juga yang menyatakannya untuk melindungi masyarakat, yang sebetulnya juga

$42 \quad$ Muslim Zainuddin (n 11), hlm. 17-18.

43 Wahbah Az-Zuhaili (n 32), hlm. 263.

44 Muslim Zainuddin (n 11), hlm. 17. 
menjadi tujuan dari tiga tujuan sebelumnya.

Sistem pemidanaan yang berlaku dalam hukum pidana nasional memang harus diakui belum dapat memberikan manfaat yang signifikan bagi pembinaan prilaku, karena ditinjau dari segi efek jera ternyata hukuman penjara belum begitu menjadi shock teraphy bagi para pelaku tindak pidana, hal ini terbukti dengan banyaknya pelaku kejahatan yang telah menjalani hukuman penjara kemudian mengulangi kembali perbuatannya, bahkan banyak yang diantaranya keluar masuk penjara karena sistem pembinaan yang dilakukan oleh Lembaga Pemasyarakatan ketika menjalani hukuman tidak mampu merubah perilaku para nara pidana menjadi lebih baik. ${ }^{45}$

Dampak buruk perbuatan zina ditimpakan secara khusus pada pelakunya dan secara umum kepada umat manusia. Bahaya zina pada kasat mata tidak satupun orang yang dapat mengingkari baik orang yang beriman atau tidak beriman, sebab dampak buruk perbuatan keji itu sudah nyata. Diantara bahaya perbuatan zina tersebut ialah: ${ }^{46}$

Jika dilihat dari aspek medis (ilmu kedokteran) zina memiliki banyak konsekuensi, diantaranya:

1. Penyakit menular seksual (PMS)

2. Infeksi

3. Infertilitas

4. Kanker

5. HIV / AIDS

6. Penderita penyakit kelamin Herves

7. Penyakit Herves genetalis

8. Siklus virus penyakit gonore

9. Mengalami kudis yang parah di stadium 2

10. Stadium tiga, ditandai dengan pembengkakakn di tubuh.

Sedangkan dari aspek sosial psikologi, pelaku zina (seks bebas) akan mendapat beberapa konsekuensi diantaranya:

1. Kualitas mentalis pada penderita (pelaku) akan rendah bahkan cendrung memburuk.

2. Kualitas kesehatan reproduksi, ini erat kaitannya dengan dampak medis karena kondisi fisik alat reproduksinya tidak berfungsi dengan baik.

3. Kualitas pendidikan, apabila terjadi dalam suatu rumah tangga peran orang tua sebagai pendidik tidak berfungsi dengan baik karena mengalami kelainan psikis dan mental.

4. Kualitas partisipasi dalam pembangunan, pelaku zina tidak mampu mendukung dalam pembangunan sebab kondisi fisik, mental, dan sosial yang kurang baik.

Ibnu Taimiyah mengatakan diantara rahmat dan kasih sayang Allah Swt adalah, diberlakukannya hukum untuk berbagai kasus kejahatan yang terjadi di antara manusia, baik kejahatan terhadap jiwa (nyawa), kejahatan terhadap fisik , kejahatan terhadap kehormatan, kejahatan terhadap harta, kejahatan pembunuhan, kekerasan fisik (melukai), kejahatan menuduh orang lain berbuat zina, dan kejahatan pencurian. ${ }^{47}$

Allah SWT memberlakukan berbagai bentuk hukuman atas berbagai bentuk kejahatan tersebut dengan sangat sempurna dan akurat yang mengandung kemaslahatan pencegahan, preventif dan menimbulkan efek jera. Namun semua itu tetap dilakukan

$45 \quad$ Ibid., hlm. 6.

46 'Tujuan Umum Tentang Zina Dan Problematikannya' (Skripsi) <http://repository.uin-suska. ac.id/6475/3/BAB II.pdf> accessed 5 July 2018. 
secara proporsional dengan berlandaskan pada asas keadilan dan tidak melampaui batas-batas pencegahan yang berhak diterapkan kepada pelaku. Oleh sebab itu, Allah SWT tidak memberlakukan hukuman potong lidah atau hukuman mati atas perbuatan berbohong, tidak memberlakukan hukuman pengebirian atas perbuatan zina dan tidak pula memberlakukan hukuman mati atas kejahatan pencurian. ${ }^{48}$

Akan tetapi, Allah SWT memberlakukan hukuman bagi manusia atas berbagai kejahatan tersebut sesuai dengan Asma dan sifat-sifat Nya, seperti kebijaksanaan, rahmat, kasih sayang, kebaikan dan keadilan-Nya, agar berbagai musibah hilang, tidak ada ambisi dan dorongan untuk saling menganiaya, setiap manusia puas dan senang dengan apa yang telah diberikan kepadanya oleh Sang Pemilik dan Sang Penciptanya, sehingga ia tidak memiliki dorongan keinginan untuk merampas hak orang lain. ${ }^{49}$

\section{Analisis Penetapan Sanksi Bagi Pelaku Zina}

\section{Profil Qanun Dan Enakmen}

a. Qanun Aceh dan Sejarah Singkat Pembentukan Qanun

Kata Qanun berasal dari bahasa Arab yang berarti Undang-undang. Qanun dapat juga bermakna Undang-undang sejenis peraturan daerah provinsi yang mengatur penyelenggaraan pemerintahan dan kehidupan masyarakat Aceh. (Pasal 1 butir 21 UUPA), ${ }^{50}$

Qanun dibuat oleh pemerintah Aceh dan disahkan oleh Dewan Perwakilan Rakyat (DPR) yang di tanda tangani oleh Gubernur (tingkat provinsi) dan bupati atau walikota pada daerah tingkat dua. Dasar berlakunya Qanun adalah undang-undang tentang otonomi khusus Aceh. Dalam undang-undang nomor 18 disebutkan bahwa mahkamah syar'iyah akan melaksanakan syariat Islam yang di tuangkan ke dalam Qanun terlebih dahulu. Qanun merupakan peraturan yang dibuat oleh pemerintah daerah Aceh untuk melaksanakan syariat Islam bagi pemeluknya di Aceh. ${ }^{51}$

Pembentukan Qanun sebagai instrument yuridis untuk pelaksanaan undang-undang Nomor 11 Tahun 2006 tentang pemerintahan Aceh (UUPA) dan peraturan perundangan lain serta pelaksanaan otonomi daerah akan terlaksana baik apabila didukung oleh tata cara pembentukkan, metode yang pasti, baku dan standar yang mengikat semua lembaga yang memiliki wewenang membentuk Qanun.

Secara umum langkah legal drafting (pembuatan perundang-undangan) Qanun di Nanggroe Aceh Darussalam di mulai dengan penyiapan naskah akademik, inventarisasi masalah dan penyusunan sistematika. Ketiga ini tidak mesti berurutan. Setelah ini barulah dilakukan penulisan draf awal Qanun yang dilanjutkan dengan penyempurnaanpenyempurnaan yang terus diulang sampai dianggap memadai bahkan sempurna. Qanun dirancang dan disusun sebagai bagian dari upaya untuk memenuhi kebutuhan masyarakat Nanggroe Aceh Darussalam akan perundang-undangan yang berbasis syariat Islam pada masa kini dan masa depan, bukan kebutuhan masa lalu. ${ }^{52}$

Proses legislative drafting, diperlukan landasan yang meliputi Landasan yuridis, sosiologis dan filosofis. Dengan aspek yuridis dimaksudkan agar produk hukum yang diterbitkan dapat berjalan sesuai tujuan tanpa menimbulkan gejolak di tengah masyarakat. Landasan

\footnotetext{
$48 \quad$ Ibid.

49 Ibid.

50 Republik Indonesia, Undang-undang No. 11 Tahun 2006 tentang pemerintahan Aceh, dalam Pasal 1 butir 1.

51 Imam Mudaikram, 'Qanun Syariat Islam Aceh Darussalam' <https://imammudaikram.wordpress. com/2017/01/04/qanun-syariat-islam-aceh-darussalam/> accessed 4 January 2017.

52 Agus Salim, 'Jarimah Khalwat Dalam Territorial Aceh (Analisis Penerapan KUHP Dan Qanun Jinayah Aceh No. 6 Tahun 2014)' (UIN Ar-Raniry Banda Aceh 2017), hlm. 20.
} 
yuridis meliputi tiga hal:

a. Kewenangan dari psembuatan undang-undangan,

b. Kesesuaian bentuk atau jenis peraturan perundang-undangan dengan materi yang diatur,

c. Keharusan mengikuti tata cara tertentu.

Adapun secara sosiologis, suatu produk regulasi harus mencerminkan kenyataan yang hidup dalam masyarakat. Aspek sosiologis ini dimaksudkan agar produk hukum yang diterbitkan jangan sampai bertentangan dengan nilai-nilai hakiki ditengah-tengah masyarakat, misalnya agama.

Dari penjelasan di atas penulis menyimpulkan bahwa Qanun adalah suatu peraturan atau undang-undang yang berlaku di suatu tempat (daerah) yang mana peraturan tersebut hanya berlaku untuk orang yang beragama Islam saja.

1. Asas-asas pembentukan undang-undang

Dalam pembentukan peraturan perundang-undangan harus dilakukan dengan berdasarkan asas-asas yang meliputi: ${ }^{53}$

a. Asas kejelasan tujuan

b. Kelembagaan atau pejabat pembentuk yang tepat

c. Kesesuaian antara jenis, hirarki dan materi muatan

d. Dapat dilaksanakan

e. Kedayagunaan dan kehasilgunaan

Kejelasan rumusan

f. Keterbukaan (pasal 5 UU RI Nomor 12 Tahun 2011 tentang pembentukan peraturan perundang-undangan).

Melalui PERDA yang pertama, diatur upaya pencegahan penggunaan (pengkonsumsian dan pendistribusian) khamar atau minuman beralkohol, yang sangat meresahkan masyarakat dan penjatuhan hukuman untuk para pelanggarnya. Melalui PERDA yang kedua diatur pembentukan lembaga independen yang beranggotakan para ulama, yang diberi nama Majelis Permusyawaratan Ulama (MPU). Sedang melalui tiga PERDA berikutnya diatur berbagai hal yang pada intinya adalah upaya menggalakkan pelaksanaan syari'at, serta dorongan dan permintaan (pemerintah) kepada pemerintah daerah dan masyarakat untuk menyediakan fasilitas dan menciptakan suasana guna memudahkan masyarakat melaksanakan ajaran dan tuntunan islam dalam berbagai aspek kehidupan. ${ }^{54}$

\section{Pokok-pokok materi Qanun}

Dalam rangka pelaksanaan syariat Islam secara kaffah melalui kekuasaan Negara, pemerintah Aceh telah melahirkan sejumlah Qanun Aceh, baikyang mengatur kelembagaan hukum, hukum materil maupun hukum formil (hukum acara). ${ }^{55}$ Qanun Aceh tersebut antara lain: ${ }^{56}$

* Peraturan Daerah Propinsi Daerah Istimewa Aceh No. 5 Tahun 2000 tentang Pelaksanaan Syariat Islam di Propinsi Daerah Istimewa Aceh;

* Qanun Aceh No. 10 Tahun 2002 tentang Peradilan Syari'at Islam;

* Qanun Aceh No. 11 Tahun 2002 tentang Pelaksanaan Syari'at Islam bidang Aqidah, Ibadah dan Syiar Islam;

\footnotetext{
$53 \quad$ Ibid. hal. 22

54 Al Yasa' Abubakar, Penerapan Syari'at Islam Di Aceh (Dinas Syariat Islam Aceh 2013), hlm. 201-202.

55 Diskusi tentang Qanun Jinayat dan pengembangannya dalam hukum nasional lihat, Kamarusdiana Kamarusdiana, 'Qânûn Jinâyat Aceh Dalam Perspektif Negara Hukum Indonesia' (2016) 16 AHKAM : Jurnal Ilmu Syariah, hlm. 151-162.

56 Dinas Syari'at Islam, Hukum Jinayat Dan Hukum Acara Jinayat (Naskah Aceh 2015), hlm. x-xi.
} 
* Qanun Aceh No. 12 Tahun 2003 tentang Minuman Khammar dan sejenisnya;

* Qanun Aceh No. 13 Tahun 2003 tentang Maisir (Perjudian);

* Qanun Aceh No. 14 Tahun 2003 tentang Khalwat (Mesum);

* Qanun Aceh No. 7 Tahun 2004 tentang Pengelolaan Zakat;

* Qanun Aceh No. 11 Tahun 2004 tentang Tugas Fungsional Kepolisisan Daerah Nanggro Aceh Darussalam;

* Qanun Aceh No. 19 Tahun 2008 tentang Pembinaan Kehidupan Adat dan Adat Istiadat;

* Qanun Aceh No. 10 Tahun 2008 tentang Kelembagaan Adat;

* Qanun Aceh No. 2 Tahun 2008 tentang Majelis Permusyawaratan Ulama;

* Qanun Aceh No. 10 Tahun 2010 tentang Baitul Mal;

* Qanun Aceh No. 7 Tahun 2003 tentang Hukum Acara Jinayat;

* Qanun Aceh No. 6 Tahun 2014 tentang Hukum Jinayat;

* Qanun Aceh No. 8 Tahun 2014 tentang Pokok-pokok Syariat Islam.

Dari pejelasan diatas dapat disimpulkan bahwa pokok-pokok materi Qanun yang telah diberlakukan di Aceh itu ada 15 jenis Qanun baik yang mengatur kelembagaan hukum, hukum materil maupun hukum formil (hukum acara). Dari semua Qanun yang termuat di atas penulis hanya membahas satu Qanun saja yaitu: Qanun Aceh No. 6 Tahun 2014 tentang Hukum Jinayat.

Pada tanggal 22 oktober 2014 melalui proses legislasi (taqnin) antara Dewan Perwakilan Rakyat Aceh (DPRA) dan Gubernur Aceh yang dituangkan dalam bentuk Qanun, mengesahkan satu produk hukum, yaitu Qanun No. 6 tahun 2014 tentang hukum jinayat, selanjutnya Qanun ini diundangkan pada tanggal 23 oktober 2014 dan mulai diberlakukan satu tahun kemudian, yaitu pada tanggal 23 Oktober 2015. Qanun ini relatif banyak menimbulkan pro dan kontra di berbagai kalangan baik akademisi, praktisi maupun masyarakat biasa. Pro kontra terhadap suatu kebijakan daerah, apalagi berkaitan dengan pembentukan materi hukum syariah adalah hal wajar yang perlu disikapi secara arif dan bijaksana. Pro kontra terhadap qanun jinayah ini tidak hanya muncul di daerah, tapi juga di tingkat nasional. ${ }^{57}$ Pada taraf tertentu pro kontra tersebut mengarah pada penolakan dan penentangan terhadap pemberlakuan Qanun hukum Jinayah di Aceh. ${ }^{58}$ Penyelenggaraan hukum Jinayat berasaskan pada: 1 . Keislaman, 2. Legalitas, 3. Keadilan dan Keseimbangan, 4. Kemaslahatan, 5. Perlindungan hak asasi manusia, 6. Pembelajaran kepada masyarakat (tadabbur)..$^{59}$

Qanun Aceh No. 6 Tahun 2014 tentang hukum jinayat terdiri atas 10 (sepuluh) BAB dan 75 (tujuh puluh lima) pasal. Pada dasarnya Qanun Aceh No. 6 Tahun 2014 tentang Hukum Jinayat mengatur 3 (tiga) hal, yaitu pelaku pidana, perbuatan pidana (jarimah) dan ancama pidana ('Uqubat).$^{60}$ Adapun pokok-pokok materi yang terkandung dalam Qanun Aceh No. 6 Tahun 2014 tentang Hukum Jinayat meliputi;

1) Zina

2) Qadzaf

3) Pemerkosaan/Pelecehan seksual

4) Khamar

5) Maisir

6) Khalwat

57 Nasrullah Yahya, 'Legislasi Hukum Positif (Fikih) Aceh: Tinjauan Pergumulan Qanun Hukum Jinayah' (2015) 14 IJTIHAD Jurnal Wacana Hukum Islam dan Kemanusiaan $149<$ http://ijtihad.iainsalatiga. ac.id/index.php/ijtihad/article/view/163>.

58 Ibid., hlm. xi.

59 Ibid. hlm 11

60 Ibid., hlm. xiv-xv. 
7) Ikhtilath

8) Liwath

9) Pemerkosaan

Terkait zina Qanun No. 6 Tahun 2014 tentang hukum jinayat diatur dalam pasal 33 ayat (1) yang berbunyi: setiap orang yang dengan sengaja melakukan jarimah zina diancam dengan 'Uqubat hudud cambuk 100 (seratus) kali. Adapun ayat (2) berbunyi setiap orang yang mengulangi perbuatan sebagaimana dimaksud pada ayat (1) diancam dengan 'Uqubat hudud cambuk 100 (seratus) kali dan dapat ditambah dengan 'Uqubat Ta'zir denda paling banyak 120 (seratus dua puluh) gram emas murni atau 'Uqubat Ta'zir penjara paling lama 12 (dua belas) bulan. Serta ayat (3) yang berbunyi: setiap orang dan / badan usaha yang dengan sengaja menyediakan fasilitas atau mempromosikan jarimah zina, diancam dengan 'Uqubat Ta'zir cambuk paling banyak 100 (seratus) kali dan atau denda paling banyak 1000 (seribu) gram emas murni dan atau penjara paling banyak 100 (seratus) bulan. ${ }^{61}$

Perumusan ini bertumpu pada budaya dan adat istiadat lokal masyarakat Indonesia, khususnya Aceh, serta berkolaborasi dengan sistem hukum yang berlaku di dalam NKRI. ${ }^{62}$ Dengan demikian filosofi, asas, tujuan dan prinsip yang dikandung hukum jinayat atau hukum acara jinayat menunjukkan adanya paradigma baru hukum di Aceh. Para penegak hukum dan masyarakat diharapkan mampu mewujudkan sebuah tatanan hukum fiqh baru yang berakar dan menyatu dengan kesadaran hukum rakyat.

b. Profil Enakmen dan Sejarah singkat pembentukan Enakmen Syariah Negeri Selangor

Malaysia sebagai negara muslim di Asia Tenggara yang secara geografis, kultur, dan historis sangat dekat denganIndonesia, khususnya dengan Nanggore Aceh Darussalam. Salah satudari (13) tiga belas negara bagian di Malaysia, Selangor Darul Ehsan, menerapkan juga syariat Islam. Salah satu syariat Islam yang diberlakukan di Selangor adalah Enakmen Jenayah Syariah (Enakmen 9Tahun 1995) yang disetujui oleh Sultan Salahuddin Abdul Aziz Shah Al-Haj 10 Januari 1996 dan mulai berlaku 22 November 1996. Enakmen yang terdiri dari 55 Seksyen dan 8 Bahagian ini mengaturbeberapa tindak pidana, di antaranya tentang kesalahan yang berhubungan dengan akidah, berhubungan dengan kesucian agama Islam dan institusinya, berhubungan dengan kesusilaan, dan lain-lain.

Sejarah penulisan hukum berbentuk Enakmen ini bermula pada akhir abad ke-19 selepas (setelah) orang Inggris mengusai tanah Melayu. Ini berarti bahwa langkah memperkenal dan menguat kuasakan Enakmen ini berkait rapat (erat) dengan sejarah kekuasaan mereka di negara ini. Pada peringkat permulaan (pertama), mereka memperkenalkan enakmen ini di negeri-negeri selat dan negeri-negeri Melayu Bersekutu, karena Negeri-negeri inilah yang mula-mula (pada awalnya) dikuasai oleh mereka. Kemudian baru dilanjutkan penggunaannya ke negeri-negeri Bernaung, karena mereka menguasai negeri-negeri ini selepas (setelah) mereka menguasai negeri-negeri selat dan negeri-negeri Melayu Bersekutu. $^{63}$

\section{Penulisan Enakmen di negeri-negeri Selat}

Pada tahun 1826, kerajaan British mencantumkan Singapura, Melaka dan Pulau Pinang dibawah satu pentadbiran. Hasil pencantuman itu, negeri-negeri tersebut dikenali

61 Ibid., hlm. 24-25.

62 Diskusi lebih lanjut mengenai perumusan Qanun Jinayah lihat, Nyak Fadhlullah, 'Metode Perumusan Qanun Jinayah Aceh : Kajian Terhadap Pasal 33 Tentang Zina' (2017) 7 in Right (Jurnal Agama dan Hak Azazi Manusia ) 16 <http://ejournal.uin-suka.ac.id/syariah/inright/article/view/1456/1262>.

63 Abdul Kadir bin H. Muhammad, Sejarah Penulisan Hukum Islam Di Malaysia (Perpustakaan Negara Malaysia), hlm. 99. 
sebagai negeri-negeri Selat. Pada awalnya mereka tidak memperkenalkan apa-apa (apa saja) bentuk perundangan mengenai Islam. Pada tahun 1880, lima puluh empat tahun kemudian, barulah mereka memperkenalkan undang-undang mengenai perkahwinan dan perceraian orang Islam. Undang-undang ini disebut Mahomedan Ordinance, No. 5 of $1880 .{ }^{64}$ Dengan terlaksananya undang-undang tersebut, maka ini merupakan perundangan terawal berbentuk Enakmen yang berhubungan dengan Islam yang pernah diperkenalkan oleh penjajah British setelah mereka mencampuri urusan pemerintahan di negeri-negeri Melayu. ${ }^{65}$

\section{Negeri Selangor}

Agama Islam di Negeri Selangor telah terwujud seaawal kurun 15 yang telah datang melalui Melaka. Ini karena pada waktu itu Selangor berda di bawah jajahan Melaka. Pada zaman pemerintahan Melaka telah ada jawatan kadi. Pada tahun 1884, Majlis Mesyuarat Negeri Selangor mengiktirafkan jawatan kadi dan imam, setelah itu mengambil keputusan untuk melantik seorang kadi untuk menyelesiaikan segala masalah hukum-hukum agama Islam dan juga adat istiadat Melayu. Pada saat itu juga DYMM sultan Selangor telah melantik seorang kadi dsebut sebagai "kadi Selangor" dengan memberi gaji sebanyak RM 900.00 pertahun dan priode ini hanya berlaku hingga tahun 1892.

Undang-undang mencegah berzina Tahun 1894 adalah undang-undang pertama yang dikanunkan di negeri Selangor. Diluluskan olek majlis Mesyuarat Negeri Selangor pada 26 September 1894 dan undang-undang ini hanya berkuatkuasa (berlaku) untuk orang yang beragama Islam saja.

Pada tahun 1900 juga, jawatan kadi mula diperluaskan ke daerah-daerah dalam negeri Selangor dan pada tahun 1922 tiap-tiap daerah adakadinya masing-masing, yaitu daerah Klang, Kuala Lumpur, Kuala Langat, Ulu Langat, Kuala Selangor, Sabak Bernam, Kuala Kubu dan Rawang.

Negeri Selangor turut memperkenalkan enakmen pentadbiran mengenai Islam. Antara enakmen terawal yang dikuatkuasakan ialah perintah maengenai pelantikan kadi, pendaftaran perkahwinan, perceraian dan kematian dikalangan orang islam. Ini terkandung dalam order in Council of jun 14 thn 1884. Peruntukan ini memberi kuasa kepada kadi untuk menyelesaikan pertikaian yang timbul mengenai islam. Imam-imam dikehendaki menyimpan rekod pendaftaran perkahwinan, perceraian dan kematian orang Islam. ${ }^{66}$

Pada tahun 1948 Jabatan Agama Islam Selangor (JAIS) telah ditubuhkan, dengan itu usaha menggubah undang-undang telah dilakukan dan menghasilkan Undang-undang Pentadbiran agama Islam Selangor No.3 tahun 1952 dengan nama Enakmen Undangundang Pentadbiran Agama Islam SelangorNo. 3 Tahun 1952 dan mula dikuatkuasakan pada 5 desember,1952. Dengan adanya undang-undang ini maka termasukhlah undangundang terdahulu daripadanya. Sehingga ke hari ini undang-undang ini telah mengalami pindaan sebanyak 7 kali yaitu pada tahun 1969, 1960, 1961, 1962, 1966, 1972 dan pada 1979. Pindaan ini dibuat berkaitan dengan urusan mengemaskinikan pentadbiran hal ehwal Islam di negeri Selangor.

Pada tahun 1989 Enakmen Perundangan Islam Selangor No. 2 Tahun 1989 telah diluluskan. Berdasarkan enakmen inilah Mahkamah Syariah Selangor ditubuhkan secara rasmi dan berasingan dari Jabatan Agama Islam Selangor (JAIS). Pada tahun 1991, Enakmen Kanun Prosedur Jenayah Syariah Selangor No. 6 Tahun 1991 dan Enakmen Kanun Prosedur Mal $64 \quad$ Ibid. hlm 100

65 Ibid.

66 Ibid. hlm 116 
Syariah Selangor No. 7 tahun 1991 telah diluluskan dan mula dikuatkuasakan pada tanggal 1 September 1991. Mulai dari tanggal itu, Mahkamah Syariah Selangor telah diasingkan secara rasminya dari JAIS. Pada tahun 2003 nama Mahkamah Syariah Selangor telah ditukar kepada Jabatan Kehakiman Syariah Negeri Selangor selaras dengan perkembangan dan peningkatan kualitas perkhidmatannya kepada pelanggan.

Enakmen Jenayah Syariah Negeri Selangor (Enakmen 9 Tahun 1995) yang disetujui oleh Sultan Salahuddin Abdul Aziz Shah Al-Haj 10 Januari 1996 dan mulai berlaku 22 November 1996 terdiri dari 55 Seksyen dan 8 Bahagian. Enakmen ini mengatur beberapa tindak pidana, di antaranya tentang kesalahan yang berhubungan dengan akidah, berhubungan dengan kesucian agama Islam dan institusinya, berhubungan dengan kesusilaan, dan lainlain. ${ }^{67}$

Mengenai dengan Undang-undang yang mengatur tentang Mencegah Berzina Tahun 1894 (Prevenatation of Adultry Regulation 1894) merupakan undang-undang pertama yang dikanunkan di negeri Selangor. Diluluskan oleh Majlis Mesyuarat Negeri Selangor pada 26 September, 1894 dan undang-undang ini hanya berkuatkuasa untuk orang Islam sahaja. ${ }^{68}$

Menurut undang-undang ini, seorang laki-laki yang melakukan hubungan kelamin dengan seorang perempuan yang telah bersuami adalah bersalah dan boleh dihukum 2 tahun penjara bagi laki-laki dan 1 tahun penjara bagi perempuan dan mungkin kedua-duanya di kenakan denda. Dalam masalah ini mahkamah akan bertindak ke atas laporan yang dibuat oleh suami perempuan itu atau orang lain yang bertanggungjawab atas perempuan itu di mana sekiranya suaminya tiada. ${ }^{69}$ Peruntukan ini diperuntukkan hukuman orang Islam yang melakukan zina. ${ }^{70}$

\section{Hukuman Terhadap Pelaku Zina}

1. Hukuman Terhadap Pelaku Zina dalam Qanun No. 6 Tahun 2014 tentang Hukum Jinayat

Di dalam Qanun Jinayat Aceh Nomor 6 Tahun 2014 tentang Hukum Jinayat dinyatakan bahwa hukuman bagi pelaku zina adalah di cambuk 100 (seratus) kali, hal ini sebagai mana disebutkan dalam pasal 33 mengenai zina yang berbunyi:

(1) Setiap orang yang dengan sengaja melakukan jarimah zina, diancam dengan 'Uqubat Hudud cambuk 100 (sratus) kali.

(2) Setiap orang yang mengulangi perbuatan sebagaimana dimaksud pada ayat(1) diancam dengan 'Uqubat Hudud cambuk 100 (sratus) kali dan dapat ditambah dengan 'Uqubat Ta'zir denda paling banyak 120 (seratus dua puluh) gram emas murni atau 'Uqubat Ta'zir penjara paling lama 12 bulan. $^{71}$

(3) setiap orang dan/badan usaha yang dengan sengaja menyediakan fasilitas atau mempromosikan jarimah zina, diancam dengan 'Uqubat ta'zir cambuk paling banyak 100 (seratus) kali dan/atau denda paling banyak 1000 (seribu) gram emas murni dan/atau penjara paling banyak (100) seratus bulan.

Dari pasal tersebut di atas, penulis menyimpulkan bahwa ada tiga pengelompokan 67 Ahmad Bahiej, 'Studi Komparatif Terhadap Qanun Aceh Tentang Hukum Jinayat Dan Enakmen Jenayah Syariah Selangor Malaysia' (2014) Vol. 48, N Jurnal Ilmu Syari'ah dan Hukum <https:// www.researchgate.net/publication/315694021_Studi_Komparatif_terhadap_Qanun_Aceh_tentang_ Hukum_Jinayat_dan_Enakmen_Jenayah_Syariah_Selangor_Malaysia>.

68 'Profil Mahkamah Syariah Shah Alam Selangor' <http://repository.uin-suska.ac.id/6405/3/BAB II.pdf> accessed 15 July 2018.

69 Ibid.

70 Abdul Kadir bin H. Muhammad (n 60), hlm. 116.

71 Dinas Syari'at Islam (n 55), hlm. 24-25. 
hukuman zina. Pertama, pelaku zina yang pertama kali melakukan dikenakan hukuman cambuk 100 (seratus) kali. Kedua, pelaku zina yang telah berulang kali melakukan zina, selain dikenakan cambuk 100 (seratus) kali, juga dikenakan denda paling banyak 120 (seratus dua puluh) gram emas atau penjara paling lama 12 bulan. Ketiga, setiap orang dan/badan usaha yang dengan sengaja menyediakan fasilitas atau mempromosikan jarimah zina, diancam dengan 'Uqubat ta'zir cambuk paling banyak 100 (seratus) kali dan/atau denda paling banyak 1000 (seribu) gram emas murni dan/atau penjara paling banyak (100) seratus bulan.

Dalam rumusan pasal 33 ayat (1) terdapat Unsur-unsur sebagai berikut:

1. Unsur "Setiap Orang"

Sesuai dengan ketentuan pasal 1 angka 38 Qanun Nomor 6 tahun 2014 bahwa yang dimaksud unsur "setiap orang" adalah orang perorangan, atau setiap orang yang beragama Islam yang melakukan jarimah (tindak pidana) di Aceh (pasal 5), ${ }^{72}$ sehingga terhadap orang tersebut dapat dimitakan pertanggung jawaban terhadap suatu jarimah yang dilakukan.

2. Unsur pekerjaan yang dilakukan yaitu "sengaja berbuat zina"

Yang dimaksud dengan kesengajaan adalah itikad jahat seseorang yang dengan sengaja melakukan hal tersebut, padahal ia mengetahui bahwa perbuatan itu diharamkan. ${ }^{73}$ Yang dimaksud dengan unsur sengaja "berzina" adalah dengan sengaja, sadar, atas kemauan sendiri dan tanpa paksaan dari orang lain untuk melakukan perbuatan zina.

3. Unsur objek yang melakukan

Sesuai dengan ketentuan pasal 1 angka 26 bahwa yang dimaksud dengan Zina adalah persetubuhan antara seorang laki-laki atau lebih dengan seorang perempuan atau lebih tanpa ikatan perkawinan dengan kerelaan kedua belah pihak. ${ }^{74}$

Berdasarkan ketentuan di atas, hukuman yang dikenal di dalam qanun yaitu jilid (cambuk) 100 (seratus) kali. Yang diatur secara tegas hanya yang berkaitan dengan pelaksanaan eksekusi cambuk. Peraturan Gubernur No. 10 Tahun 2005 tentang Petunjuk Teknis pelaksanaan Uqubat Cambuk diantaranya menetapkan hal-hal tersebut. ${ }^{75}$

1. Pelaksanaan eksekusi adalah jaksa.

2. Penyediaan fasilitas dan persiapan dilakukan oleh Dinas Syari'at Islam.

3. Pencambukan dilakukan ditempat yang dapat disaksikan banyak orang denagan dihadiri jaksa penuntut umum dan dokter yang ditujnuk.

4. Pencambukan dilakukan dengan rotan yang berdiameter $1 \mathrm{Cm}$, panjang $1 \mathrm{M}$ dan tidak mempunyai ujung ganda/belah.

5. Pencambukan dilakukan pada bagian tubuh kecuali kepala, muka, leher, dada dan kemaluan.

6. Kadar pukulan atau pencambukan tidak sampai melukai.

7. Terhukum laki-laki dicambuk dalam posisi berdiri tanpa penyangga, tanpa diikat dan memakai baju tipis yang menutup aurat. Sedangkan perempuan dalam posisi duduk dan ditutup kain diatasnya.

8. Pencambukan terhadap perempuan hamil dilakukan setelah 60 hari yang

$72 \quad$ Ibid., hlm. 13.

73 Rahmat Hakim, Hukum Pidana Islam (Fiqh Jinayah) (Pustaka Setia 2000), hlm. 98.

74 Dinas Syari'at Islam (n 55), hlm. 7.

75 Dinas Syari'at Islam, Himpunan Undang-Undang, Keputusan Presiden, Peraturan Daerah/Qanun, Instruksi Gubernur, Berkaitan Pelaksanaan Syari'at Islam (Edisi 8, Dinas Syariat Islam Aceh 2010), hlm. 669. 
bersangkutan melahirkan.

Dari uaraian di atas penulis menyimpulkan bahwa hukuman yang ditetapkan dalam Qanun Nomor 6 Tahun 2014 yaitu hukuman cambuk. Hukuman tersebut adalah hukuman yang eksekusinya dikenakan terhadap pelaku tindak pidana zina, disamping berdampak jera bagi si pelaku, juga berdampak buruk terhadap keluarga dan lingkungannya. Disebabkan karena hukuman atau 'Uqubat cambuk yang dijatuhkan terhadap pelaku zina dapat memberikan efek jera bagi pelaku baik secara fisik maupun secara psikologi karena proses eksekusi hukumannya dilakukan di depan khalayak umum. Namun akibat yang ditimbulkan dari hukuman cambuk bukan hanya dari segi fisik semata dan juga dapat terancam dari segi sosiologis. Menurut penulis, hukuman cambuk merupakan hukuman terbaik yang bisa memberantas masalah zina.

Namun demikian Qanun jinayat Aceh ini tidak membedakan hukuman antara penzina muhsan dan pezina ghairu muhsan, dimana pezina muhsan itu hukumannya adalah rajam. Hal ini dikarenakan berdasarkan wawancara penulis dengan sejumlah pemerhati Qanun. Qanun Aceh ini adalah tahap pertama yang dia tidak ada bersifat menghilangkan nyawa, dan juga apabila pelaksanaan hukuman cambuk telah terealisasi secara mantap maka itu bisa dipertimbangkan untuk menambah hukuman rajam bagi pelaku zina yang berstatus muhsan.

\section{Hukuman Terhadap Pelaku Zina Menurut Enakmen Syariah Negeri Selangor}

Menurut Enakmen Syariah Negeri Selangor, hukuman yang diberikan kepada pelaku zina, ada beberapa alternatif sanksi hukum sebagaimana yang tertuang di dalam enakmen jinayah syariah negeri Selangor seperti berikut:

a. Seorang laki-laki atau perempuan yang melakukan persetubuhan atau kelakuan sumbang (selingkuh) dengan seorang wanita atau lelaki mengikut mana mana yang berkenaan, dimana hubungan di antara mereka adalah muabbad mengikut hukum syara', adalah melakukan suatu kesalahan dan hendaklah apabila disabitkan (dibuktikan), dikenakan hukuman denda tidak melebihi lima ribu ringgit (Rp. 17.500,000,00), atau penjara selama tempoh (waktu) tidak melebihi tiga tahun dan boleh juga dikenakan sebat (cambuk) tidak melebihi daripada enam kali.

b. Seorang wanita yang melacurkan dirinya adalah melakukan suatu kesalahan dan hendaklah apabila dibuktikan kesalahan, dikenakan hukuman denda tidak melebihi lima ribu ringgit ( $R p .17 .500,000,00)$, atau penjara selama tempoh (waktu) tidak melebihi tiga tahun atau kedua-duanya.

c. Barang siapa yang melakukan persetubuhan adalah bersalah atas suatu kesalahan dan hendaklah apabila dikuatkan kesalahan, dikenakan hukuman denda tidak melebihi lima ribu ringgit (Rp. 17.500,000,00), atau penjara selama tempoh (waktu) tidak melebihi tiga tahun dan boleh juga dikenakan sebat (cambuk) tidak melebihi daripada enam kali.

d. Siapa saja yang melakuka percubaan peersetubuhan haram adalah bersalah atas suatu kesalahan dan hendaklah apabila dikuatkan kesalahan, dikenakan hukuman benda dikenakan hukuman denda tidakmelebihi lima ribu ringgit (Rp. 17.500,000,00), atau penjara selama tempoh (waktu) tidak melebihi tiga tahun atau kedua-duanya.

e. Seseorangyang hamil atau melahirkan bayi luar nikah akibat daripada persetubuhan haram yang dilakukan dengan kerelaan dan kesadarannya adalah melakukan suatu kesalahan dan hedaklah apabila dikuatkan kesalahan, dikenakan hukuman benda dikenakan hukuman denda tidak melebihi lima ribu ringgit (Rp. 17.500,000,00), atau penjara selama tempoh (waktu) tidak melebihi tiga tahun atau kedua-duanya.

f. Barang siapa melakukan perbuatan besekedudukan (kumpul kebo) adalah bersalah 
atas suatu kesalahan dan hendaklah apabila dikuatkan kesalahan, dikenakan hukuman benda dikenakan hukuman denda tidak melebihi lima ribu ringgit (Rp. 17.500,000,00), atau penjara selama tempoh (waktu) tidak melebihi tiga tahun atau kedua-duanya.

Dari penjelasan tentang sanksi hukum bagi pelaku zina yang tercantum dalam enakmen jinayah syariah negeri Selangor di atas, dapat disimpulkan bahwa sanksi hukum bagi pelaku zina dapat dibagi kepada tiga jenis sanksi yang diberlakukan, yaitu sanksi hukum denda, penjara dan sebatan (cambuk). Namun demikian dalam pelaksanaannya yang lebih sering diberlakukan adalah sanksi hukum denda dan penjara. Sementara sanksi hukum sebatan jarang sekali dilakukan, karena hukuman sebatan (cambuk) biasanya sebagai hukuman tamabahan atau pengganti untuk penahanan dan sebuah alternatif untuk denda. ${ }^{76}$

Dengan demikian pelaksanaan hukuman bagi pelaku jarimah zina di mahkamah syariah negeri Selangor dapat dikategorikan kepada hukuman ta'zir saja. Pada dasarnya jarimah hudud (mencuri, meminum minuman keras, dan zina) tidak diberlakukan terhadap hukum ta'zir tetapi, jika keadaan memerlukan hukuman ta'zir dapat diterapkan terhadap pelaku jinayah hudud seperti zina dengan alasan untuk kepentingan umum. Hukuman ta'zir terhadap pelaku jinayah hudud dapat diberlakukan dengan syarat: ${ }^{77}$

a. Telah melakukan perbuatan yang menyentuh kepentingan atau maslahat umum.

b. Hukum digunakan untuk kepentingan umum.

Untuk memunculkan pelaksanaan sanksi hukum terhadap pelaku jarimah hudud yang sesuai dengan kategori sanksi hukum yang terdapat dalam Enakmen Jinayah Syariah terutama sanksi sebatan (cambuk) perlu diupayakan langkah-langkah, diantaranya pemerinah hendaklah memberikan pemahaman tentang undang-undang Islam kepada masyarakat majmuk (umum).

\section{Analisis Dengan Teori Pemidanaan}

Mengenai teori pemidanaan pada umumnya dapat dikelompokkan dalam tiga golongan besar, yaitu teori absolut atau teori pembalasan (vergeldings theorien), teori relatif atau teori tujuan (doel theorien), dan teori menggabungkan (verinigings theorien). ${ }^{78}$

\section{Teori Absolut atau Teori Pembalasan}

Menurut teori ini pidana dijatuhkan karena orang telah melakukan kejahatan. Pidana sebagai akibat mutlak yang haris ada sebagai suatu pebalasan kepada orang yang melakukan kejahatan. Jadi dasar pembenarannya terletak pada adanya kejahatan itu sendiri.

\section{Teori Relatif atau Teori Tujuan}

Teori Relatif atau Teori Tujuan juga disebut teori tilitarian, lahir sebagai reaksi terhadap teori absolut. Secara garis besar, tujuan pidana menurut teori relatif bukanlah sekedar pembalasan, tetapi untuk mewujudkan ketertiban di dalam masyarakat.

$76 \quad$ Muslim Zainuddin (n 11), hlm. 135.

77 Muhamad Hafizul bin MD. Ahayar, 'Hukuman Bagi Pezina Menurut Fikih Syafi'I Dan Enakmen (Undang-Undang Jinayah Negeri Selangor’ (UIN Syarif Hidayatullah) <http://repository.uinjkt.ac.id/ dspace/bitstream/123456789/5075/1/MUHAMAD HAYAFIZUL BIN MD. AHAYAR-FSH.pdf>. teori pemidanaan dalam kajian hukum Islam, lihat lebih lanjut dalam Junaidi Abdillah, 'Gagasan Reaktualisasi Teori Pidana Islam Dan Relevansinya Bagi Pembangunan Hukum Di Indonesia' (2017) 10 Ijtimaiyya: Jurnal Pengembangan Masyarakat Islam, hlm. 63-95, lihat juga Nafi' Mubarok, 'Tujuan Pemidanaan Dalam Hukum Pidana Nasional Dan Fiqh Jinayah' (2015) 18 Al-Qanun, hlm. 296-323. 
Jadi tujuan pidana menurut teori relatif adalah untuk mencegah agar ketertiban di dalam masyarakat tidak terganggu. Dengan kata lain, pidana yang dijatuhkan kepada si pelaku kejahatan bukanlah untuk membalas kejahatannya, melainkan untuk mempertahankan ketertiban umum. ${ }^{79}$

\section{Teori Gabungan}

Menurut teori gabungan bahwa tujuan pidana itu selain membalas kesalahan penjahat juga dimaksudkan untuk melindungi masyarakat, dengan mewujudkan ketertiban. Teori ini menggunakan kedua teori di atas (teori absolut dan teori relatif) sebagai dasar pemidanaan, dengan pertimbangan kedua teori tersebut memiliki kelemahan-kelemahan yaitu:

a. Kelemahan teori Absolut adalah menimbulkan ketidakadilan karena dalam penjatuhan hukuman perlu mempertimbangkan bukti-bukti yang ada dan pembalasan yang dimaksud tidak harus Negara yang melaksanakan.

b. Kelemahan teori relatif yaitu dapat menimbulkan ketidakadilan karena pelaku tindak pidana ringan dapat dijatuhi hukuman berat.

Dalam pandangan penulis mengenai hukuman bagi pelaku zina. Penulis cendrung ke arah Qanun, Karena dalam Qanun No. 6 Tahun 2014 hukuman bagi pelaku zina adalah 'Uqubat hudud cambuk 100 (seratus) kali dan itu merupakan ketentuan yang telah secara jelas disebutkan di dalam dalil (al-Quran). Karena objektivitas dikembalikan kepada al- Quran dan hadits dan teori-teori hukum Islam, dalam hal ini maqasid syariah dan dengan menggunakan penalaran terhadap nash yaitu maslahah mursalah atau penalaran istislahi dari situlah akan didapatkan ke objektifannya. Yang sangat penulis sayangkan adalah dalam Qanun Jinayat Aceh ini tidak menbedakan antara hukuman bagi pelaku zina muhsan dan pelaku zina ghairu muhsan.

Pada bab dua sudah disebutkan bahwa tujuan pemidanaan untuk jarimah zina adalah, melindungi nasab, pembalasan atas kejahatan atau perbuatan pidana yang dilakukan, mencegah pelaku melakukan perusakan badan atau kejiwaan orang lain, memberi efek jera sehingga tidak lagi mengulangi perbuatan tersebut, mendidik dan memperbaiki pelaku perbuatan pidana dan untuk melindugi masyatakat.

Analisis Qanun Aceh ini jika dilihat Sudah disebutkan bahwa dalam Qanun jinayat hukuman bagi pelaku zina adalah cambuk (Jilid) 100 (seratus) kali, denda dan penjara. Karena jarimah tersebut ialah jarimah hudud, dan hukuman hudud tersebut tidak dapat dirubah lagi, baik ditambah maupun dikurang. Hukuman hudud terbagi tiga macam, yaitu hukuman mati, hukuman potong tangan, dan cambuk disertai dengan pengasingan.

Dilihat dari tujuan pemidanaan di atas yaitu, melindungi nasab, pembalasan atas kejahatan atau perbuatan pidana yang dilakukan, mencegah pelaku melakukan perusakan badan atau kejiwaan orang lain, memberi efek jera dan mendidik serta memperbaiki pelaku perbuatan pidana dan untuk melindugi masyatakat. Semua tujuan yang tersebut di atas termasuk kepada maqasid al-shari'ah yaitu keperluan asas daruriyyah ada lima perkara yang menjadi teras kehidupan manusia yaitu agama, jiwa, akal, keturunan (nasab) dan harta.

Sistem pemidanaan yang berlaku dalam hukum pidana nasional memang harus diakui belum dapat memberikan manfaat yang signifikan bagi pembinaan prilaku, karena ditinjau dari segi efek jera ternyata hukuman penjara belum begitu menjadi shock teraphy bagi para pelaku tindak pidana, hal ini terbukti dengan banyaknya pelaku kejahatan yang

79 Usman, 'Analislis Perkembangan Teori Hukum Pidana' (2012) Vol. 2, No Jurnal Ilmu Hukum <https:// online-journal.unja.ac.id/index.php/jih/article/view/54>. 
telah menjalani hukuman penjara kemudian mengulangi kembali perbuatannya, bahkan banyak yang diantaranya keluar masuk penjara karena sistem pembinaan yang dilakukan oleh Lembaga Pemasyarakatan ketika menjalani hukuman tidak mampu merubah perilaku para nara pidana menjadi lebih baik.

Jika dilihat dari bentuk hukuman yang ada di dalam Qanun Aceh menurut hemat penulis sudah tercapai tujuan pemidanaan yang dimaksud di atas, karena hukuman cambuk yang terdapat dalam Qanun dapat memberi efek jera dan mendidik bagi si pelaku zina, adapun tujuan melindungi masyarakat ialah karena pelaksanaan hukuman tersebut di hadapan orang banyak.

Sedangkan hukuman yang terdapat dalam Enakmen Syariah Negeri Selangor ialah berbentuk denda, yang mana menurut hemat penulis tidak mencapai sampai ketujuan pemidanaan yang telah disebutkan diatas. Karena hukuman utamanya adalah berbentuk denda yang mana hukuman itu tidak akan memberi efek jera serta tidak mendidik si pelaku zina tersebut. bahkan kesalahan tersebut bisa saja terulang kembali.

Berikut ini penjelasan mengenai jenis hukuman dan persamaan serta perbedaan hukuman yang terdapat dalam Qanun Aceh dan Enakmen Syariah negeri Selangor:

Tabel persamaan dan perbedaan hukuman bagi pelaku zina menurut qanun Aceh dan enakmen syariah negeri Selangor

\begin{tabular}{|c|c|c|}
\hline No & Hukuman dalam Qanun & Hukuman dalam Enakmen \\
\hline 1 & Cambuk (jilid) & Denda \\
\hline 2 & Penjara (kurungan) & Penjara (kurungan) \\
\hline 3 & Denda & Cambuk (sebat) \\
\hline
\end{tabular}

Table 3.2.Tabel Persamaan dan Perbedaan

\begin{tabular}{|c|c|c|}
\hline No & Persamaan & Perbedaan \\
\hline 1 & $\begin{array}{l}\text { Pada prinsipnya, kedua aturan } \\
\text { tersebut hanya diberlakukan } \\
\text { kepada orang Islam. Qanun Syariah } \\
\text { Aceh memberikan kelonggaran bagi } \\
\text { orang non-Islam dalam hal adanya } \\
\text { penundukan secara sukarela } \\
\text { terhadap Qanun. }\end{array}$ & $\begin{array}{l}\text { Hukum cambuk sama-sama } \\
\text { diatur di kedua tempat tersebut } \\
\text { namun perbedaannya adalah } \\
\text { jika dilihat dari sisi sanksinya, } \\
\text { Qanun Hukum Jinayat Nomor } 6 \\
\text { Tahun } 2014 \text { memberikan sanksi } \\
\text { lebih berat. Secara umum Qanun } \\
\text { Hukum Jinayat mengancam pidana } \\
\text { cambuk sampai maksimal } 100 \text { kali, } \\
\text { denda maksimal } 2.000 \text { gram emas } \\
\text { murni, dan penjara } 125 \text { bulan (10 } \\
\text { tahun } 5 \text { bulan), sedangkan dalam } \\
\text { Enakmen Syariah Jenayah Selangor } \\
\text { mengancam dengan sanksi pidana } \\
\text { denda paling banyak RM.5.000.00, } \\
\text { penjara paling banyak } 3 \text { tahun, dan } \\
\text { sebat paling banvak } 6 \text { kali sebatan. }\end{array}$ \\
\hline
\end{tabular}




\begin{tabular}{|c|c|c|}
\hline 2 & $\begin{array}{l}\text { Kedua aturan hukum tersebut } \\
\text { hanya berlaku di tingkat provinsi } \\
\text { atau tingkat negara bagian. Qanun } \\
\text { Syariah Aceh hanya berlaku di } \\
\text { wilayah Provinsi Naggroe Aceh } \\
\text { Darussalam, sementara Enakmen } \\
\text { Jenayah Syariah Selangor hanya } \\
\text { berlaku di wilayah Selangor. }\end{array}$ & $\begin{array}{l}\text { Hukuman denda, adapun hukuman } \\
\text { denda juga sama-sama diatur } \\
\text { dalam kedua perundang-undangan } \\
\text { tersebut, hanya saja di dalam } \\
\text { Enakmen hukuman denda menjadi } \\
\text { sanksi utama bagi pelaku zina. }\end{array}$ \\
\hline 3 & $\begin{array}{l}\text { Kedua aturan hukum tersebut } \\
\text { mengancam sanksi pidana bagi } \\
\text { pelanggarnya berupa sanksi dera/ } \\
\text { sebatan, denda, dan penjara. }\end{array}$ & \\
\hline 4 & $\begin{array}{l}\text { Dalam Qanun Aceh terdapat hukum } \\
\text { cambuk bagi pelaku zina. Begitu } \\
\text { pula dengan Enakmen Syariah } \\
\text { Negeri Selangor juga mengatur } \\
\text { hukum cambuk bagi pezina. }\end{array}$ & \\
\hline 5 & $\begin{array}{l}\text { Penjara, di dalam Qanun Aceh juga } \\
\text { mengatur ketentuan mengenai } \\
\text { hukuman penjara bagi pelaku zina. } \\
\text { Dan di dalam Enakmen Syariah } \\
\text { Negeri Selangor juga mengatur } \\
\text { ketentuan yang sama. }\end{array}$ & \\
\hline 6 & $\begin{array}{l}\text { Denda, adapun sanksi denda } \\
\text { di kedua peraturan tersebut ( } \\
\text { Qanun Aceh dan Enakmen Syariah } \\
\text { Negeri Selangor) juga sama-sama } \\
\text { mengatur sanksi tersebut. }\end{array}$ & \\
\hline
\end{tabular}

\section{Penutup \\ Kesimpulan}

Dari beberapa pembahasan yang telah diuraikan pada bab-bab diatas, maka penulis menarik kesimpulan sebagai berikut:

1. Zina adalah persetubuhan antara seorang laki-laki atau lebih dengan seorang perempuan atau lebih tanpa ikatan perkawinan dengan kerelaan kedua belah pihak, yang mana hukuman bagi pelaku zina diatur dalam Qanun No.6 Tahun 2014 tentang Hukum Jinayat yang di jelaskan dalam pasal 33 bahwa pelaku di ancam diancam dengan 'Uqubat Hudud cambuk 100 (sratus) kali. Dalam Enakmen Syariah 
Negeri Selangor, hukuman yang diberikan kepada pelaku zina, ada beberapa alternative sanksi hukum yang diklasifikasikan kepada tiga, yaitu sanksi hukum denda, penjara dan sebatan (cambuk).

2. Adapun yang melatarbelakangi perbedaan penetapan atau jumlah sanksi di kedua tempat tersebut ialah karena berbeda asas dalam penetapan hukuman bagi pelaku jarimah. Dalam penetapan hukuman bagi pelaku jarimah di dalam Qanun berdasarkan asas keislaman (syari'at Islam) yang mana di dalam fiqh mengatur hukuman bagi pelaku zina adalah cambuk 100 (seratus) kali. Adapun asas yang menjadi dasar dalam pembentukan hukuman bagi pelaku jinayah dalam Enakmen bersasaskan kepada kemaslahatan. Hukuman cambuk yang di berlakukan di Selangor merupakan alternative ketiga dari hukuman bagi pelaku zina, karena dalam penetapan hukuman bagi pelaku tindak pidana di Malaysia menggunakan hukuman Ta'zir.

\section{Saran}

Adapun saran-saran yang dikemukakan penulis berkaitan dengan judul yaitu:

1. Bagi Pemerintah

- Diharapkan kepada pihak pemerintah agar dapat mensosialisasikan Qanun Jinayat No. 6 Tahun 2014 tentang Hukum Jinayat keseluruh masyarakat Aceh, agar tidak ada lagi masyarakat yang tidak taat hukum akibat ketidaktahuan terhadap hukuman yang telah diatur oleh pemerintah dan hukuman apa saja yang telah diberlakukan ditempat dimana ia tinggal.

2. Bagi Akademisi

- Diharapkan kepada pihak kampus dan perpustakaan, agar dapat menambah dan memperbanyak buku-buku tentang hukum jinayat dan buku Qanun Aceh untuk bahan bacaan serta wawasan mahasiswa dan juga sebagai referensi-referensi penelitian sebagai perbandingan.

- Penulis menyarankan kepada pihak dekan Fakultas Syari'ah agar sudi kiranya mempublikasikan skripsi ini baik dalam bentuk buku, majalah, jurnal dan lainnya, sehingga karya ini bisa di jadikan sebagai bahan rujukan, baik dikalangan dosen maupun mahasiswa yang ada di lingkungan kampus UIN Ar-raniry khususnya Fakultas Syari'ah.

Inilah saran-saran yang dapat penulis ambil dari karya ilmiah ini, semoga karya ilmiah ini bermamfaat, diberkati Allah SWT, dan menjadi bahan rujukan untuk kajian seterusnya, Aamiin

\section{DAFTAR PUSTAKA}

A. Hanafi, Azas-Azas Hukum Pidana Islam (Bulan Bintang 1967)

Abdillah J, 'Gagasan Reaktualisasi Teori Pidana Islam Dan Relevansinya Bagi Pembangunan Hukum Di Indonesia' (2017) 10 Ijtimaiyya: Jurnal Pengembangan Masyarakat Islam 63

Abdul Kadir bin H. Muhammad, Sejarah Penulisan Hukum Islam Di Malaysia (Perpustakaan Negara Malaysia)

Aceh DSI, Hukum Jinayat Dan Hukum Acara Jinayat (Naskah Aceh 2015) 
Agus Salim, 'Jarimah Khalwat Dalam Territorial Aceh (Analisis Penerapan KUHP Dan Qanun Jinayah Aceh No. 6 Tahun 2014)’ (UIN Ar-Raniry Banda Aceh 2017)

Ahmad Bahiej, 'Studi Komparatif Terhadap Qanun Aceh Tentang Hukum Jinayat Dan Enakmen Jenayah Syariah Selangor Malaysia' (2014) Vol. 48, N Jurnal Ilmu Syari'ah dan Hukum <https://www.researchgate.net/publication/315694021_ Studi_Komparatif_terhadap_Qanun_Aceh_tentang_Hukum_Jinayat_dan_Enakmen_ Jenayah_Syariah_Selangor_Malaysia>

Al-Bukhari, Sahih Al- Bukhari

Al-Hafizh Ibnu Hajar Al-'Asqalani, Bulughul Maram (PT Fathan Prima Media 2014)

Al Yasa' Abubakar, Penerapan Syari'at Islam Di Aceh (Dinas Syariat Islam Aceh 2013)

Departemen Pendidikan Nasional, Kamus Besar Bahasa Indonesia (Gramedia 2011)

Dinas Syari'at Islam, Himpunan Undang-Undang, Keputusan Presiden, Peraturan Daerah/ Qanun, Instruksi Gubernur, Berkaitan Pelaksanaan Syari'at Islam (Edisi 8, Dinas Syariat Islam Aceh 2010)

——, Hukum Jinayat Dan Hukum Acara Jinayat (Naskah Aceh 2015)

E. Untrech, Hukum Pidana I (Universitas Jakarta 1958)

Fadhlullah N, 'Metode Perumusan Qanun Jinayah Aceh : Kajian Terhadap Pasal 33 Tentang Zina' (2017) 7 in Right (Jurnal Agama dan Hak Azazi Manusia) $16<$ http://ejournal. uin-suka.ac.id/syariah/inright/article/view/1456/1262>

H.A. Djazuli, Fiqh Jinayah (PT Raja Grafindo Persada 1997)

Ibnu Hajar Al-Asqalani, Bulughul Maram (Gema Insani 2013)

Ibnu Rusyd, Bidayatul Mujtahid Wa Nihayatul Muqtashid (Akbar Media Eka Sarana 2013)

Ida Noverayanti, 'Hukuman Bagi Pelaku Zina Dewasa Dengan Anak-Anak (Perbandingan Fiqh Jinayah Dan Qanun No. 6 Tahun 2014 Tentang Hukum Jinayat' (UIN Ar-Raniry 2017)

Imam Mudaikram, 'Qanun Syariat Islam Aceh Darussalam' <https://imammudaikram. wordpress.com/2017/01/04/qanun-syariat-islam-aceh-darussalam/> accessed 4 January 2017

Irfan Hidayat, 'Hukum Pengasingan Bagi Pezina Ghair Muhsan (Study Perbandingan Antara Mazhab Hanafi Dan Syafi'i' (UIN Ar-Raniry 2014)

Irfan M dan MN, Fiqh Jinayah (Amzah 2016)

Kamarusdiana K, 'Qânûn Jinâyat Aceh Dalam Perspektif Negara Hukum Indonesia' (2016) 16 AHKAM : Jurnal Ilmu Syariah 151

Mubarok N, ‘Tujuan Pemidanaan Dalam Hukum Pidana Nasional Dan Fiqh Jinayah' (2015) 18 Al-Qanun 296

Muhamad Hafizul bin MD. Ahayar, 'Hukuman Bagi Pezina Menurut Fikih Syafi'I Dan Enakmen (Undang-Undang Jinayah Negeri Selangor' (UIN Syarif Hidayatullah) <http://repository.uinjkt.ac.id/dspace/bitstream/123456789/5075/1/ MUHAMAD HAYAFIZUL BIN MD. AHAYAR-FSH.pdf>

Muslim bin Al-Hajjaj al-Qusyairi an-Naisaburi, Ensiklopedi Hadits Shahih Muslim (Almahira 2012) 
Muslim Zainuddin, Problematika Hukuman Cambuk Di Aceh (Dinas Syariat Islam Aceh 2012)

Nurul Irfan dan Masyrofah, Fiqh Jinayah (Sinar Grafika Offset 2014)

'Profil Mahkamah Syariah Shah Alam Selangor' <http://repository.uin-suska. ac.id/6405/3/BAB II.pdf> accessed 15 July 2018

Quthb S, Tafsir Fi- Zhilalil Qur'an (Gema Insani Press 2001)

Rahmat Hakim, Hukum Pidana Islam (Fiqh Jinayah) (Pustaka Setia 2000)

Saleh Al-Fauzan, Fiqih Sehari-Hari (Gema Insani 2005)

Sayyid Sabiq, Fiqh Sunah Jilid II (Al- I' tishom 2008)

——, Fiqih Sunnah (Insan Kamil 2016)

Sulaiman Rasjid, Fiqh Islam (Sinar Baru Algensindo 2017)

Topo Santoso, Membumikan Hukum Pidana Islam (Gema Insani Press 2003)

'Tujuan Umum Tentang Zina Dan Problematikannya' (Skripsi) <http://repository.uinsuska.ac.id/6475/3/BAB II.pdf> accessed 5 July 2018

Usman, 'Analislis Perkembangan Teori Hukum Pidana' (2012) Vol. 2, No Jurnal Ilmu Hukum <https://online-journal.unja.ac.id/index.php/jih/article/view/54>

Wahbah Al-Zuhaili, Al-Fiqh Al-Islami Wa Adillatuh (Dar Al-Fikr 1997)

Fiqh Islam Wa Adillatuhu (Jilid 7, Gema Insani 2007)

Fiqh Imam Syafi'i (Almahira 2008)

Yahya N, 'Legislasi Hukum Positif (Fikih) Aceh: Tinjauan Pergumulan Qanun Hukum Jinayah' (2015) 14 IJTIHAD Jurnal Wacana Hukum Islam dan Kemanusiaan 149 <http://ijtihad.iainsalatiga.ac.id/index.php/ijtihad/article/view/163>

Republik Indonesia, Undang-undang No. 11 Tahun 2006 tentang pemerintahan Aceh, dalam Pasal 1 butir 1 